University of Nebraska - Lincoln

DigitalCommons@University of Nebraska - Lincoln

Biology and Impacts of Pacific Island Invasive Species. 15. Psittacula krameri, the Rose-Ringed Parakeet (Psittaciformes: Psittacidae) 1

\author{
Aaron B. Shiels \\ USDA, APHIS, Wildlife Services' National Wildlife Research Center, aaron.b.shiels@aphis.usda.gov \\ Nicholas P. Kalodimos \\ University of Hawaii at Manoa
}

Follow this and additional works at: https://digitalcommons.unl.edu/icwdm_usdanwrc

Part of the Natural Resources and Conservation Commons, Natural Resources Management and Policy Commons, Other Environmental Sciences Commons, Other Veterinary Medicine Commons, Population Biology Commons, Terrestrial and Aquatic Ecology Commons, Veterinary Infectious Diseases Commons, Veterinary Microbiology and Immunobiology Commons, Veterinary Preventive Medicine, Epidemiology, and Public Health Commons, and the Zoology Commons

Shiels, Aaron B. and Kalodimos, Nicholas P., "Biology and Impacts of Pacific Island Invasive Species. 15. Psittacula krameri, the Rose-Ringed Parakeet (Psittaciformes: Psittacidae)1" (2019). USDA Wildlife Services - Staff Publications. 2314.

https://digitalcommons.unl.edu/icwdm_usdanwrc/2314

This Article is brought to you for free and open access by the U.S. Department of Agriculture: Animal and Plant Health Inspection Service at DigitalCommons@University of Nebraska - Lincoln. It has been accepted for inclusion in USDA Wildlife Services - Staff Publications by an authorized administrator of DigitalCommons@University of Nebraska - Lincoln. 


\title{
Biology and Impacts of Pacific Island Invasive Species. 15. Psittacula krameri, the Rose-Ringed Parakeet (Psittaciformes: Psittacidae) ${ }^{1}$
}

\author{
Aaron B. Shiels, ${ }^{2,4}$ and Nicholas P. Kalodimos ${ }^{3}$
}

\begin{abstract}
The rose-ringed parakeet (RRP), Psittacula krameri, has become established in at least four Pacific Island countries (Hong Kong China, Japan, New Zealand, U.S.A.), including the Hawaiian islands of Kaua'i, O'ahu, and Hawai'i. Most Pacific islands are at risk of RRP colonization. This species was first introduced to Hong Kong in 1903 and Hawai'i in the 1930s-1960s, established since 1969 in Japan, and in New Zealand since 2005 where it has repeatedly established after organized removals. The founding birds were imported cage-birds from the pet trade. In native India, RRP are generally found associated with human habitation and are considered a severe agricultural pest. In the Hawaiian Islands, RRP are increasing and expanding their geographic ranges below $500 \mathrm{~m}$ elevation. Population estimates in 2018 on Kaua'i were $\sim 6,800$ birds, which was a three-fold increase and a $22.5 \%$ annual growth rate in the prior 6 years, whereas $\mathrm{O}^{\prime}$ ahu had $~ 4,560$ birds with a $21 \%$ annual growth rate the prior 9 years; these rates suggest a population doubling time of $\sim 3.5$ years. Wild RRP can live $14+$ years, can reproduce after 1.5 years, and have few effective predators. Breeding pairs produce 1-3 fledglings annually. RRP are seed predators and rarely seed dispersers; their flock-foraging behavior can result in severe damage to orchard and field agricultural crops including tropical fruit and corn (Zea mays), and such economic damages are especially pronounced on Kaua'i. Island societies should prevent new introductions and consider RRP deterrents and population control methods to protect resources.
\end{abstract}

Keywords: agricultural crop and orchard loss, economic costs, human-wildlife interaction, parrot damage management, pest eradication, pet trade, ring-necked parakeet, urban bird ecology

\footnotetext{
${ }^{1}$ Manuscript accepted 13 August 2019.

${ }^{2}$ USDA, APHIS, National Wildlife Research Center, 4101 LaPorte Avenue, Fort Collins, CO 80521, USA.

${ }^{3}$ University of Hawai'i at Manoa, 1910 East West Road, Honolulu, HI 96822, USA.

${ }^{4}$ Corresponding author (e-mail: aaron.b.shiels@usda. gov).
}

Pacific Science (2019), vol. 73, no. 4:421-449 doi: $10.2984 / 73.4 .1$

This article was created by a U.S. government employee and is on the Public Domain. Public domain information may be freely distributed and copied, but it is requested that in any subsequent use the U.S. Department of Agriculture and the journal, Pacific Science, be given appropriate acknowledgment.
PSITTACULA KRAMERI, THE ROSE-RINGED Or ringnecked parakeet, has been introduced to over 40 countries, gaining its status as the most widely introduced parrot in the world. Although regarded as a strikingly beautiful bird by many people, this species is a severe agricultural pest that establishes and reproduces rapidly, aggregates nightly in large roosts in human-inhabited areas, and is disruptive to humans via its noise and fecal pollution. Aside from a few locations in northern Europe where some of the public cherish this species in the wild (Menchetti et al. 2016, Crowley et al. 2019), rose-ringed parakeets are generally unwanted invaders where they have established. 
Rose-ringed parakeets are native to the tropical and subtropical parts of Africa and Asia, but they have established, expanded, and persisted in both tropical and temperate regions of the world (Butler 2005). On Pacific islands, four countries (Hong Kong China, Japan, New Zealand, and U.S.A.) have established rose-ringed parakeet populations; however, most islands in the Pacificspecifically islands from southern Canada to central Chile in the eastern Pacific, to islands from northern Japan to central New Zealand in the western Pacific - are potentially at risk of rose-ringed parakeet colonization. The climate and latitudinal ranges (ca. $56^{\circ} \mathrm{N}$ to $44^{\circ} \mathrm{S}$ ) of these Pacific islands match the ranges where they have established elsewhere in the world. Islands with human habitation are most at risk of rose-ringed parakeet establishment (Strubbe et al. 2015), as humans often enhance habitat (e.g., by planting trees used by parakeets for nesting and feeding) and provide bird feeders. This species' prevalence in the pet trade and in zoos increases the chances of its wild establishment by escaping, or being released, from cages (Reino et al. 2017, Avery and Shiels 2018).

While few data on non-native parrots exist for Pacific islands (Runde et al. 2007), our review draws on studies of the rose-ringed parakeet from both its non-native range in the Pacific and other parts of the world and its native Indian range. Due to the rapid increases in population growth and damage resulting from this species during the last 5-10 years in Hawai $i$, we feel this review is particularly timely to both prevent more islands from being colonized by these invasive birds, and to motivate population management to help reduce and prevent future damage and economic losses.

\section{NAME AND DESCRIPTION}

\section{Species Description}

Psittacula krameri is in the Class: Aves, Order: Psittaciformes, Family: Psittacidae, Subfamily: Psittacinae, Genus: Psittacula (Cuvier, 1800). Some common English names for this species are: green long-tailed parakeet, long-tailed parakeet, ring-necked parakeet, rose-ringed parakeet, and Senegal long-tailed parakeet. The official American Ornithologists Union common name is rose-ringed parakeet.

The rose-ringed parakeet (RRP) is classified into four geographically distinctive subspecies of which only the South Asian subspecies, P. krameri manillensis (Bechstein, 1800) and P. k. borealis (Neumann, 1915), are thought to be naturalized in the State of Hawai'i (Pyle and Pyle 2009, N.P.K., pers. obs.), Hong Kong, Japan, and New Zealand; genetically these two subspecies are the most represented across worldwide RRP populations (Strubbe and Matthysen 2009a), and their predominance correlates with the higher numbers transported outside their native range via the pet trade (Jackson et al. 2015). These South Asian subspecies are not easily distinguishable from one another, but have subtle morphometric differences and geographic origins; $P$. $k$. manillensis originates south of latitude $20^{\circ} \mathrm{N}$ in India and in Sri Lanka, whereas $P$. $k$. borealis originates north of $20^{\circ} \mathrm{N}$ in India, as well as in Pakistan, Bangladesh, Nepal, and Myanmar (Juniper and Parr 1998, Menchetti et al. 2016). The two African subspecies are $P$. k. krameri (Scopoli, 1769) and P. k. parvirostris (Souance, 1856), and to our knowledge they have not naturalized in the Pacific region. Psittacula $k$. krameri is from the equatorial regions in central and western Africa, and is found in Guinea, Senegal, and southern Mauritania in the east, to western Uganda and southern Sudan (Juniper and Parr 1998). Psittacula k. parvirostris is limited to the eastern equatorial region of the African continent-northwest Somalia west across northern Ethiopia to the Sennar district of Sudan. These two African subspecies were exported in lesser numbers and are not naturalized in the Pacific; they were recorded as being wild-living in Puerto Rico (Atlantic Ocean) but they failed to establish (M. Oberle, pers. comm.).

\section{Intra-Specific Variation}

The African subspecies differ physically from the two Indian subspecies in being smaller and lighter green with a yellow wash throughout. The facial area is light yellow-green and 
contrasts with the more intense grey-blue wash to the posterior head and nape. African subspecies' bills are smaller and dark red or maroon distally grading to black in contrast to the larger red bills of the Indian subspecies (Forshaw 1989, Juniper and Parr 1998).

Pithon and Dytham (2001) examined 180 museum specimens of RRP and determined that body length and bill length were the parameters that were most likely to differ among the four subspecies of RRP, and toe and wing length were also helpful in distinguishing some of the subspecies. Thus, there are subtle morphometric differences among the four subspecies, but due to $P$. $k$. manillensis being the most common species introduced, including throughout the Pacific, we have focused our review on this subspecies.

\section{Distinguishing Features}

Psittacula $k$. manillensis is a $38-42 \mathrm{~cm}$ long (body + tail) parrot, with its tail accounting for about half of its length ( $25 \mathrm{~cm}$; Butler 2005). In Europe, adult RRP generally weigh about $140 \mathrm{~g}$ (Butler and Gosler 2004). RRP on Kaua' $\mathrm{i}$ averaged $133 \mathrm{~g}$, but 12 of the 17 individuals weighed were juveniles; the four adult males averaged $139 \mathrm{~g}$ (Gaudioso et al. 2012). RRP are generally uniform light emerald green and the upper and lower mandibles of the bill are red. Like all parrots, RRP have zygodatyl feet-they have two forward-pointing and two backwardpointing toes-are brightly colored, possess short and stout strongly hooked beaks, and have relatively short legs (Figure 1).

RRP are sexually dichromatic, with the most obvious characteristic distinguishing

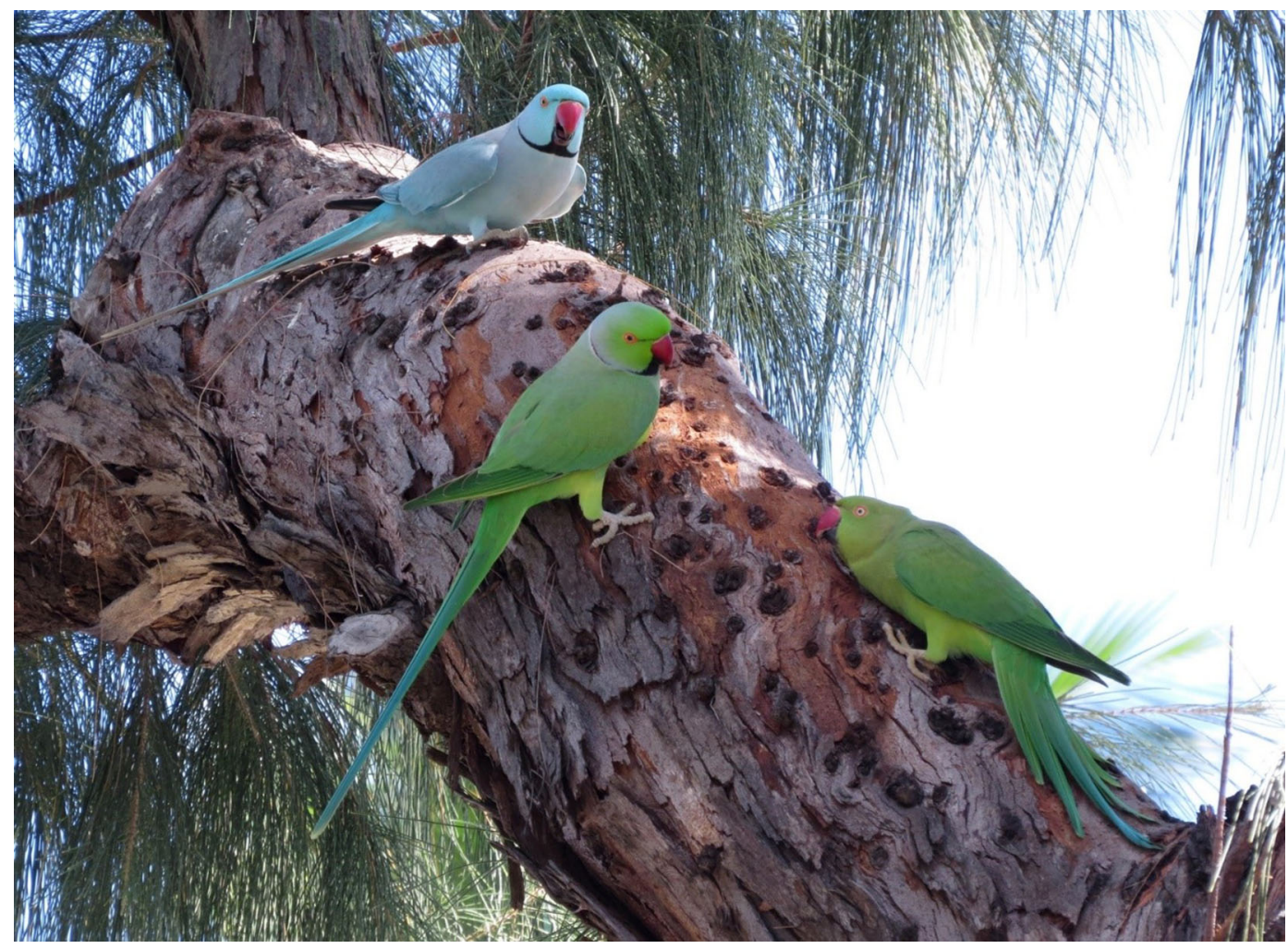

FIGURE 1. Rose-ringed parakeets (Psittacula krameri) on an ironwood tree (Casuarina equisetifolia) adjacent to Kapi'olani Park, O'ahu, Hawai'i. The upper two individuals are males (notice distinctive dark ring around neck), and the lower individual is a presumed adult female (notice faint green ring around neck, and shorter tail). The uppermost bird is a rare blue variety, with no more than three individuals known on $\mathrm{O}^{\prime}$ ahu. Photograph by Phil Taylor. 
adult males from females being that males possess a black ring around their neck. The black ring extends from the chin to both sides of the head, and a thin rose-colored ring is present under the black ring around the nape. Females lack a dark neck ring but instead have a faint pale green neck ring that is indistinct (Figure 1). Males have a black line above their bill that extends to their eyes, whereas this line is absent or less pronounced in females. Tail length of adult males is typically a few centimeters longer than the tail of adult females and juveniles (Forshaw 1989; Figure 1). The central tail feathers, especially in older males, are washed in cobalt blue near the terminus and central vein, whereas females usually possess shorter central tail feathers with less blue coloration than males (Figure 1). Juveniles and individuals up to the age of 3 years of both sexes look similar to mature females. Adults of both sexes have a thin orangecolored skin ring surrounding the eye, and the eye has a two-toned tan (outer) and grey (inner) colored iris, whereas immature birds younger than six-months old have dark grey irises and no eye ring coloration. Adult plumage starts to appear at 18 months and is completed by 32 months. Young males lacking distinguishing adult male plumage may successfully pair and reproduce (Butler 2003). Feet are greenish-grey in both sexes and ages (Butler 2003).

The very long tail, emerald green monotypic coloration, and distinct call (listen at: https:// www.parrots.org/encyclopedia/ringneck-para keet) make the RRP fairly easy to distinguish from other parrot species that have been established in Hawai' $i$ and other Pacific Islands. In addition to the RRP, at least four other species of parrots have established localized reproducing populations in Hawai' $i$, and these four species (blue-crowned parakeet Thectocercus acuticaudatus, mitred parakeet Psittacara mitratus, red-masked parakeet Psittacara erythrogenys, and red-crowned parrot Amazona viridigenalis) are detailed in VanderWerf and Kalodimos (in review). Specifically, the bluecrowed parakeet has a blue crown and pale beak; the mitred parakeet, red-masked parakeet, and red-crowed parrot each have green bodies but have red on their heads.
Hong Kong and Japan have non-native Alexandrine parakeet (Psittacula eupatria) established, which is a close relative of the RRP (diverging from a common ancestor about 5 million years ago; Groombridge et al. 2004). The Alexandrine parakeet could be confused with RRP because of the emerald color, long tail feathers, red bill, and black neck ring on the males. However, the Alexandrine parakeet is about one-third longer (58 cm long), 80\% heavier (250-260 $\mathrm{g})$, and its bill is significantly larger than that of the RRP. Other common names for the Alexandrine parakeet include the greater roseringed parakeet, great-billed parakeet, and Alexandrine ring-necked parakeet. The call of the Alexandrine parakeet is also known to be louder and harsher than that of the RRP (https://www.parrots.org/encyclopedia/alex andrine-parakeet). Additional parrots established on Pacific islands where RRP have invaded are easily distinguishable from RRP (e.g., cockatoos (Cacatua spp.) in Hong Kong and Hawai' $i$, budgerigar (Melopsittacus undulatus) in Japan and Hawai'i, native parrots of New Zealand).

\section{ECONOMIC IMPORTANCE AND ENVIRONMENTAL IMPACT}

\section{Foraging}

Negative economic and environmental impacts by parrots are largely related to foraging activities. In general, most parrot species that have naturalized in the Pacific, including the RRP, are largely pre-dispersal granivores (seed predators) (Galetti 1993, del Hoyo et al. 1997, Corlett 1998, Mack and Wright 2005, Kalodimos 2008, Shiels et al. 2018; Figure 2). Parrots have specialized bill and tongue morphologies to be able to extract, dismember, and process seeds for ingestion (Collar 1997, Corlett 1998). Parrot foraging impacts in the wild are primarily related to seed destruction and damage, serving as net seed "sinks" rather than one of seed dispersing "sources." Thabethe et al. (2015) assessed whether RRP disperse seeds during captive trials, and found that RRP were mainly seed predators of the tested species; however, some 


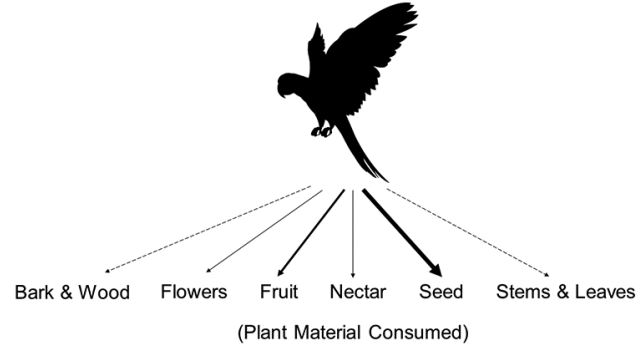

Figure 2. Generalized diet of the rose-ringed parakeet (Psittacula krameri), a strict herbivore, with arrow thickness indicating average relative abundance of food items consumed. Dashed lines indicate food items that have been recorded as being consumed but are extremely rare in the average diet. The thinnest solid arrows indicate infrequent items by volume (in crop + gizzard contents) but commonly consumed seasonally on some islands (e.g., O'ahu, Japan); the medium solid arrow (fruit) indicates nearly ubiquitous presence but low/medium relative volume; the thickest solid arrow (seed) indicates ubiquitous presence and high relative volume. All categories and relationships are based on reviewed literature (see text).

seeds were passed intact and germinated, and others were regurgitated like seeds of camphor (Cinnamomum camphora), which has $0.75 \mathrm{~cm}$ diameter seeds. Shiels et al. (2018) analyzed crop and gizzards of 64 RRP wildharvested on Kaua' $i$ and found an average of $11.6 \pm 3.3$ (min: 0, max: 150) intact seeds per individual, but were unable to determine if the grinding action of the gizzard would destroy all intact seeds. Therefore, although RRP may occasionally disperse seeds, their main behavior when handling seeds is predation (Figure 2).

Gregarious flock foraging behavior of RRP magnifies their impacts to individual trees, orchards, and crop fields. On Kaua'i, hundreds of birds may flock to corn fields to feed on the corn (Gaudioso et al. 2012), and when they feed in orchards on Kaua'i farmers report fruit loss and spoiling from RRP defecation while perched on their trees. Such fruit spoiling may account for more crop and economic loss than the direct take of fruit and seed by RRP (Novak 2018). Additionally, in Japan, the main complaint of RRP as pests is their scattering of flowers, especially cherry blossoms, when foraging for nectar (Matsunaga and Fujii 2018; Figure 2). RRP on O'ahu have proven their ability, when foraging at high densities, to eliminate a tree's ability to reproduce. Each season, RRP completely consume the seed crop of a rare $12 \mathrm{~m}$ tall Gigasiphon macrosiphon (Fabaceae) tree at the Foster Botanical Garden (located in downtown Honolulu; N.P.K. pers. obs.). RRP even extracted and killed the seeds enclosed in welded-wire mesh cages specially designed to protect the large 2-3 seeded legumes from depredation (R. Silva, pers. comm.).

\section{Degradation to Agricultural Crops}

In its native Indian range, the RRP is considered to be one of the most serious avian pests of agricultural fruit and seed crops (Ali and Ripley 1969, Shivanarayan 1981, Saini et al. 1994, Mukherjee et al. 2000). Bashir (1979) reported that the annual loss of 97,000 tons of corn seed caused by RRP in Pakistan was equivalent at the time to U.S. $\$ 15$ million. RRP feed on a wide variety of grain products and fruit (Mukherjee et al. 2000, Reddy 1998a, Reddy 1998b). For example, RRP reduced yields of corn and sorghum in parts of India by $74-81 \%$ (Reddy 1998a, Reddy 1999). Through RRP crop and gizzard analysis in India, adults and nestlings were shown to have fed primarily on sorghum, corn, and sunflower (Shivanarayan et al. 1981, Saini et al. 1994). Also in India, RRP find bean and oily seed crops highly palatable, such as red gram Cajanus cajan, green gram Phaseolus aureus, black gram $P$. mungo, Bengal gram Cicer arietinum, sunflower Helianthus anuus, safflower Carthamus tinctorius, rapeseed Brassica napus, rice Oryza sativa, and maize Zea mays (Bashir 1979, Rao and Shivanarayan 1981). In 1975, the California Department of Agriculture estimated that the potential crop losses due to a well-established RRP population could reach $\$ 735,000$ annually, a value that resulted from an estimate of RRP damaging $0.1 \%$ of crops that they are known to eat and that are grown in the area (cited in Paton et al. 1982). Vineyard damage by RRP in Surrey, U.K., was estimated at $£ 5,000$ per year (Fletcher and Askew 2007), a 0.8 ha apple orchard in Germany lost 10-15\% of its apples to RRP (Van Kleunen et al. 2010 cited in Menchetti et al. 2016), and a 0.8 ha almond 
(Prunus dulcis) orchard suffered about 30\% fruit damage from RRP in rural Italy (Mentil et al. 2018).

Although RRP are often mistaken to be indiscriminate eaters of fleshy fruit, they are most often targeting the seed within the fruit for consumption, and therefore commonly dismember fleshy fruit (ripe and unripe) to crack into the seeds (Figure 2). In India (Saini et al. 1994) and on Kaua'i (Shiels et al. 2018), yellow guava (Psidium guajava) seeds are eaten from January to March and July and August. Mulberry, Morus sp., seeds are eaten during April and May; and pearl millet Pennisetum glaucum, sorghum Sorghum bicolour, and maize from August to December (Saini et al. 1994).

Although poorly investigated, it does not appear that RRP damage to agriculture currently extends to Pacific islands besides Kaua'i and possibly O'ahu. On Kaua'i, RRP are increasing their agricultural damage to seed and orchard fruit (Koopman and Pitt 2007, Gaudioso et al. 2012, Shiels et al. 2018; Figure 2). One of the biggest agricultural economies on Kaua'i is seed corn (Z. mays), and RRP feed on the kernels of corn cobs just prior to harvest, costing farming companies hundreds of thousands of dollars in losses each year (Gaudioso et al. 2012, Avery and Shiels 2018). From a recent diet study on Kaua' $i$ and analysis of 64 birds harvested from five locations, RRP ate a range of plant food items with the primary species consumed being corn (67\% of individuals, $31 \%$ average diet by mass; mostly seed) and yellow guava seeds ( $97 \%$ of individuals, $30 \%$ average diet). Additionally, there were differences in food consumption among sites and between sexes (with males generally consuming more than females). There was no evidence of RRP consumption of insect or other animals in the 64 crop and gizzard samples analyzed (Shiels et al. 2018).

In addition to seed crops of corn and sunflower on Kaua'i (Shiels et al. 2018), RRP are significant pests of fruit trees, as they consume and damage yellow guava ( $P$. guajava), lytchi (Litchi chinensis), rambutan (Nephelium lappaceum), mangoes (Mangifera indica) and starfruit (Averroba carambola) (J. Denny, pers. comm., Koopman and Pitt 2007, Novak 2018, Shiels et al. 2018). On O‘ahu
RRP damage these same fruit crop species, as well as papaya (Carica papaya), bilimbi (Averrhoa bilimbi), and strawberry guava (Psidium cattleianum) (N.P.K., pers. obs., Runde et al. 2007; Figure 3). In general, RRP have a flexible plant diet, and food choice and usage appear to be partly related to temporal and spatial food abundance (Shiels et al. 2018) and nutritional quality. Threats to agricultural plantings from this and other parrot species is related to (1) how close the population's evening roost or active nest is to the agricultural area, and (2) the desirability of the agricultural crop as a food source relative to other food sources (Gaudioso et al. 2012, Shiels et al. 2018). On Kaua'i, most radiocollared RRP left the roost and went into nearby corn fields to feed, and daily movements appeared to reflect the spatial ripening of corn in fields (Gaudioso et al. 2012). On other Pacific islands where RRP have established, they roost in urban areas that are not near to agriculture $(\mathrm{S}$. Matsunaga, pers. comm.; L. Maria, pers. comm.; Leven and Corlett 2004). In Belgium, RRP do not nest or forage near field agricultural lands (Strubbe and Matthysen 2009a), but instead prefer lands classified as orchards (Strubbe and Matthysen 2011). Field observations from valley ridges and tall buildings on $\mathrm{O}^{\prime}$ ahu has revealed that individual RRP make daily movements of up to about $7 \mathrm{~km}$ from their evening refuge to nesting locations (N.P.K. unpubl. data). In Japan, RRP distribution appears to shift seasonally depending on food resource availability, and in some cases RRP may have widened their dietary spectrum due to occasional foraging on the ground (Matsunaga and Fujii 2018).

As in India, RRP on O'ahu forage on many leguminous tree species (Cassia spp. Caesalpinia pulcherrima, Prosopis spp., Pithecellobium dulce; Figure 3) but ignore other, heavily fruiting and abundant food species (e.g., Leucaena leucocephala, Albizia saman, Ficus spp.), indicating a possible hierarchy of food preference among plant species in their activity area on O'ahu Island. Undoubtedly, agricultural plantings are more desirable food sources than most, if not all, naturally available non-agricultural foods due to their hyper-abundance in a concentrated area; 

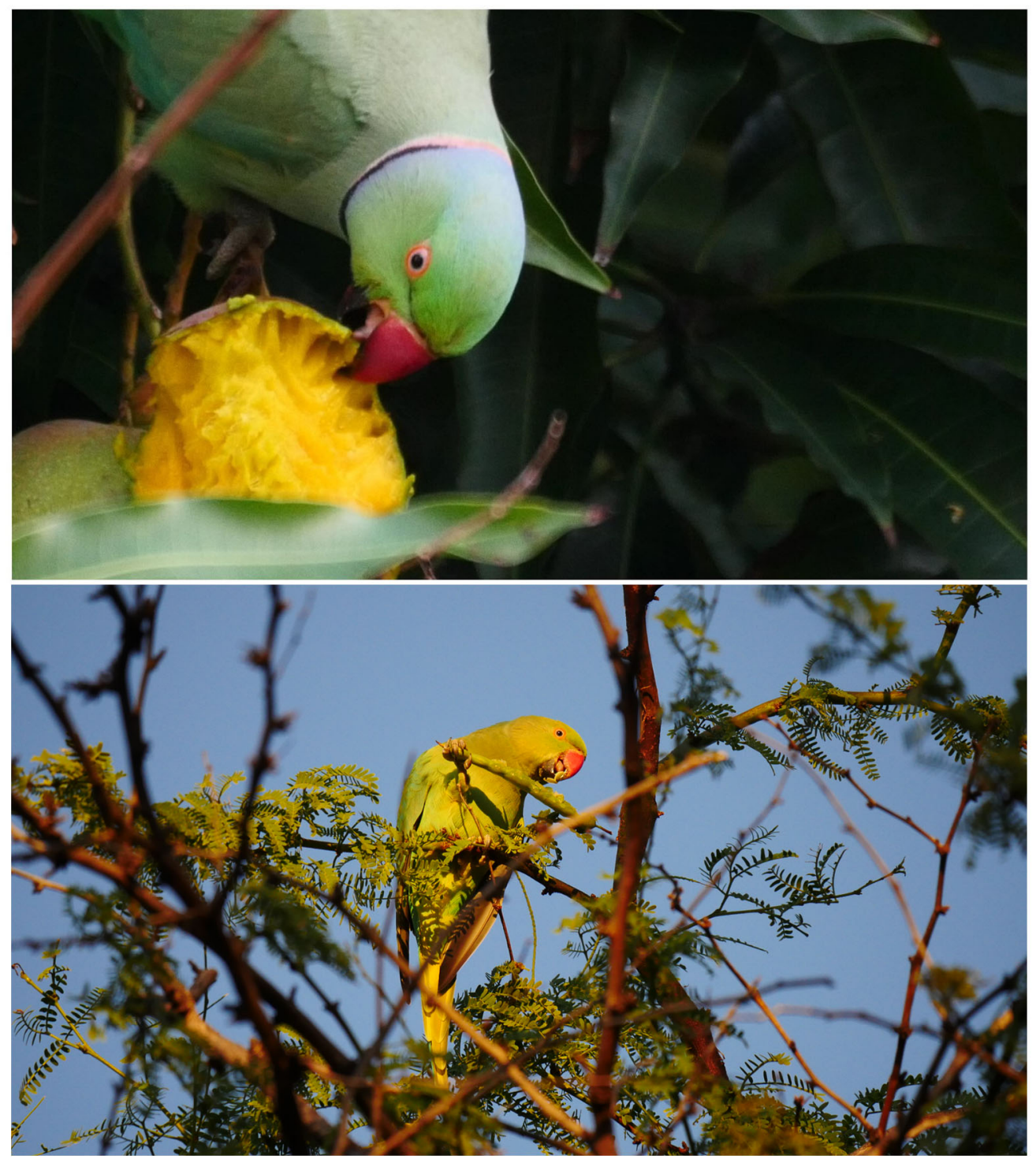

FIGURE 3. Rose-ringed parakeets consuming fruit of mango (Mangifera indica; upper picture) and 'kiawe (Prosopis pallida; lower picture) on O'ahu. Upper picture is an adult male, and lower picture is an adult female or juvenile of either sex (notice lack of dark ring around neck distinct to adult males). Photographs by N.P.K.

however, RRP appear to have preferences even among agricultural crop types.

\section{Human Interactions and Perceptions}

RRP are often perceived as a nuisance to human residents. Like many other parrot species, RRP roost colonially, often numbering tens to hundreds of individuals in single trees and thousands of individuals in groups of trees. The loudness of RRP calls is magnified from their simultaneous communications as flocks both arrive and exit roosts. On Kaua'i, $\mathrm{RRP}$ roost only in palm trees, and when the 
island's RRP population was $<3,000$ they only roosted in the royal palms (Roystonea spp.); currently RRP on Kaua'i roost in royal palms, coconut palms (Cocos nucifera), and Manila palms (Adonidia merrillii) (A.B.S., pers. obs.). Palms that line parking lots and shopping centers are regular roost sites for RRP in Kaua'i and southern California (Avery and Shiels 2018). In Japan, RRP have been observed roosting within university campuses and residential areas; however, in recent years the roosting locations have not stabilized (S. Matsunaga, pers. comm.). Tree species used for roosts in Japan include Himalayan cedar (Cedrus deodara), ginkgo (Ginkgo biloba), and bamboo (Poaceae) groves (S. Matsunaga, pers. comm.). Similarly, on Mahé (Seychelles, Indian Ocean), the main roost was a large clump of non-native bamboo that was about $30 \mathrm{~m}$ high and would contain about $300 \mathrm{RRP}$; an additional smaller roost was in albizia (Falcataria moluccana) trees (N. Bunbury, pers. comm.).

On Kaua'i, property owners of apartments, condominiums, and hotels complain about the noise from RRP calls when assembling in roosts each night at sunset, and dispersing from the roost in the early morning (Avery and Shiels 2018, Novak 2018). Similar complaints have been voiced on O'ahu, particularly from apartment residents adjacent to the largest RRP evening roost on $\mathrm{O}^{\prime}$ ahu that is a large Ficus sp. tree on Beretania and Punahou Streets (A.B.S. and N.P.K., pers. obs.). Hotel owners and local residents in Kaua'i also complain about the RRP defecation below roosting trees and the associated pests (ants, cockroaches, and mice) that they believe are elevated because of the RRP communal and repeated defecation at perches and roosts (M. Martin, pers. comm.). Additionally, RRP on Kaua'i damage non-native palms and Cook pines (Araucaria columnaris) by stripping leaves (M. Martin, pers. comm.).

In addition to the noise complaints from RRP calls in flight and at the communal roosts, RRP are hazards to airplanes and accompanying passengers. Although we know of no airplane strikes involving the RRP on Pacific islands, lethal control by shooting RRP is practiced near the runways and flight paths at Līhu'e Airport, Kaua'i, to prevent potential airstrikes (W. Bukoski, pers. comm.). From 2005 to 2006 at the Heathrow Airport in U.K., three of the 98 airplane bird strikes involved RRP, and the cost per bird strike was reported to be 220,000 (Fletcher and Askew 2007). As RRP expand in numbers and proximity to airports, airplane strikes with RRP may become more important to manage.

\section{Degradation to Natural Systems: Plants}

RRP impacts to natural areas on Pacific islands primarily involve seed predation (Figure 2), although their destruction to trees in Australia by stripping bark has resulted in some trees being killed and thereby possibly shifting the local tree community composition (Fletcher and Askew 2007). Additionally, there is evidence that non-native seeds may be dispersed by RRP in Kaua'i (Shiels et al. 2018) and South Africa (Thabethe et al. 2015), highlighting RRP as a possible vector for invasive species spread. Plants in the family Melastomataceae contain some of the most unwanted invasive plant species in the Hawaiian Islands (Medeiros et al. 1997), and these species are commonly consumed by birds and mammals, which aids in their spread (Shiels 2011). It has not been documented that RRP feed on Melastomataceae, but a captive mitred parakeet pet fed Miconia calvescens berries defecated viable seed (Gassman-Duvall 2002), leaving this as a strong possibility for RRP to do the same in the wild.

In their introduced range, RRP feed on and destroy seeds of both native and non-native plants (Cramp 1985, Strubbe and Matthysen 2007, Clergeau and Vergnes 2011). In Japan, RRP damage flowers of native cherry (Prunus spp.) blossoms when feeding on nectar (Matsunaga and Fujii 2018; Figure 4). In France and the U.K., RRP have been documented feeding on native species such as berries of holly (Ilex spp.) and elder (Sambucus spp.), and fruits and seeds of ash (Fraxinus excelsior), hornbeam (Carpinus betulus), maple (Acer campestre), yew (Taxus baccata), birch (Betula pubescens), alder (Alnus glutinosa), and willow (Salix alba) (Cramp 1985, Clergeau and Vergnes 2011). 


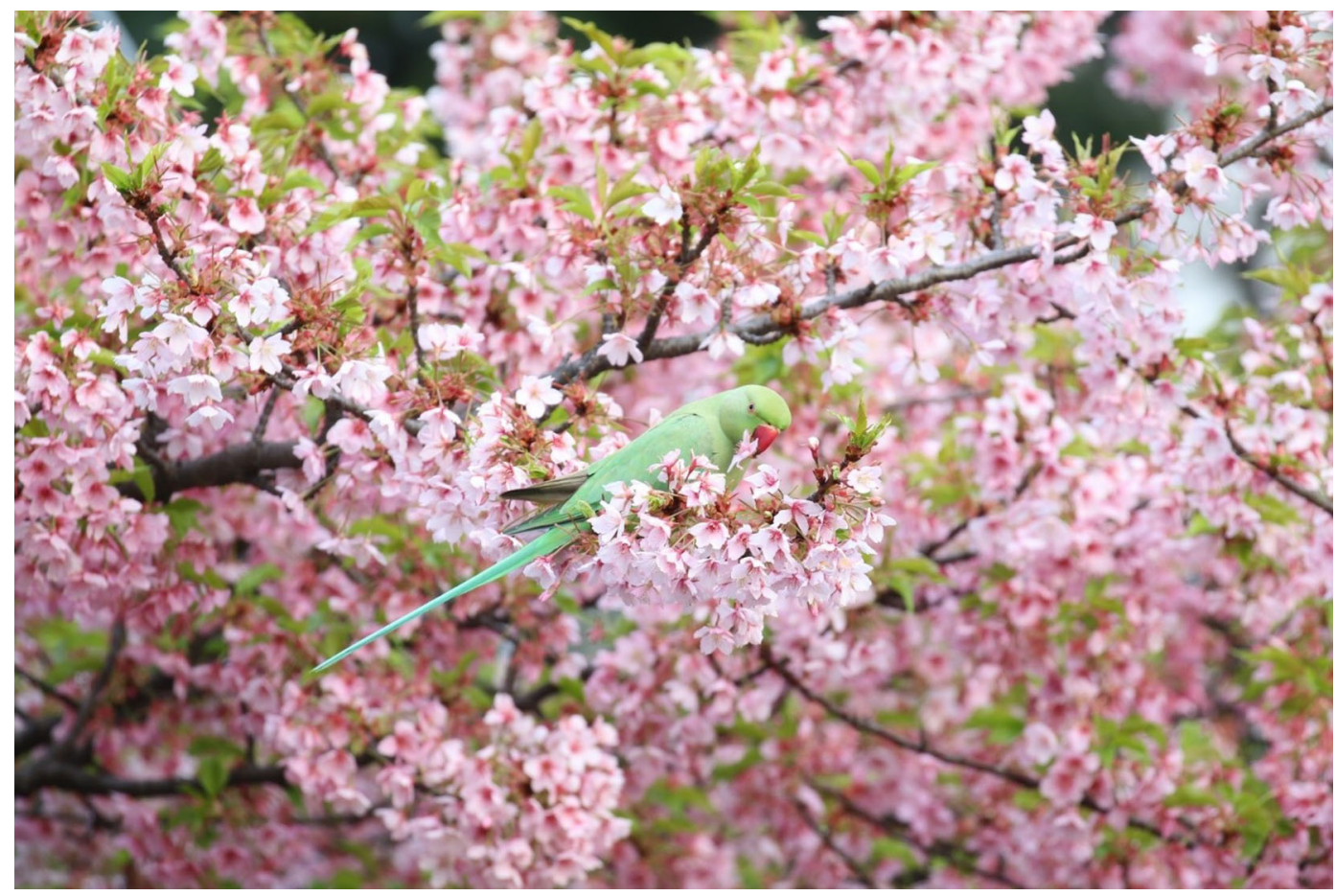

Figure 4. An adult female, or juvenile of either sex (notice lack of dark ring around neck distinct to adult males), roseringed parakeet destroying cherry blossoms (Prunus serrulata) to feed on nectar in Japan. Photograph by Satomi Matsunaga.

There has been discussion about parrots as a threat to palm species (Runde et al. 2007, Pennybacker 2016), yet RRP rarely feed on the fruit of native Hawaiian palms (Pritchardia spp.). RRP feeding on Pritchardia spp. on Kaua'i has been observed on only a few occasions, and only in planted areas (W. Bukoski, pers. comm.). Part of the very low frequency of RRP feeding on native Hawaiian Pritchardia spp. may be due to the abundant fiber and lack of fleshy pulp on their fruit. Many native Hawaiian palm species are threatened and endangered and therefore infrequently exist in the disturbed habitats where RRP exist. RRP do feed on low-fiber fruit pulp of some non-native, ornamental, palm species, such as Livistona chinensis, Archontophoenix alexandrae, and Livistona rotundifolia; however, the palm seed, cleaned of its pulp, is discarded unharmed (N.P.K., pers. obs.). RRP have also been observed feeding on a few occasions on the fruits and seeds of the leguminous native koa (Acacia koa) trees in Kaua'i (W. Bukoski, pers. comm.). Despite their documented consumption of some native plants in Europe, flower destruction in Japan, and anecdotal evidence from observations in Hawai'i, no reports yet exist indicating that RRP are altering the natural or semi-natural environment through their feeding ecology (Tayleur 2010).

RRP are known to consume nectar and flower buds (Ali and Ripley 1969, Clergeau and Vergnes 2011, Matsunaga and Fujii 2018; Figure 2). In Japan, flower damage by RRP is the main complaint from residents regarding these birds, and particularly so for the scattering of the blossoms of cherry trees while RRP are foraging on nectar (Matsunaga and Fujii 2018). On O'ahu, RRP regularly visit flowers of Erythrina species and flowers of many of the Myrtaceae, Fabaceae, and Bignoniaceae; RRP are destructive to some tree flowers especially of Cassia spp. and Pithecellobium saman (N.P.K., pers. obs.). However, general flower foraging by RRP 
lacks the thoroughness or persistence reserved for tree seed or fruit foraging. Any use of flowers by parrots in native Hawaiian forest would probably threaten restricted-range endemic Hawaiian honeycreeper food supplies and would be unacceptable. The potential for RRP and other parrot use of native Hawaiian forests should be cause for concern, though we have no evidence that RRP are foraging in native forest on any Pacific Island.

\section{Degradation to Natural Systems: Animals}

Most RRP interactions with other wildlife are avian, yet on Pacific islands the influence of RRP on native birds has not been clarified. Potential competitors of RRP in Japan may be cavity nesters such as white-cheeked starling (Spodiospar cineraceus) and the brown hawk owl (Ninox scutulata) (S. Matsunaga, pers. comm.). In Europe, RRP are known to compete with native cavity-nesting birds, and outcompete native nuthatches (Sitta europaea) (Strubbe and Matthysen 2007, Strubbe and Matthysen 2009b). Thus, a major concern for native birds on islands or regions where RRP have been introduced is the risk of being outcompeted for nesting cavities. Nest cavity competition from larger and more aggressive RRP could drive one or more species of endemic parrots of the Pacific Islands (e.g., threatened and endangered lories and lorikeets, such as Trichoglossus jobnstoniae in the Philippines, T. rubiginosus in Micronesia, and Vini ultramarina in the Marquesas) to extinction. RRP have even proven deadly to cavity roosting bat species by cornering and killing them when driving them out of tree cavities (Menchetti et al. 2014, Hernandez-Brito et al. 2018). RRP also have been observed attacking and killing squirrels (e.g., S. vulgaris) in France (Menchetti and Mori 2014), and non-native black rats (Rattus rattus) in Spain (Menchetti and Mori 2014) as the RRP pairs were apparently protecting their nests.

\section{DISEASE}

Pathogens that parrots may contract include Psittacine beak and feather disease (PBFD), avian bornavirus, chlamydiosis, Newcastle disease virus, avian pox virus, avian influenza, avian psittacosis, and pulmonary disease (England 1974, Tozer 1974). Two wild RRP in England were diagnosed via PCR and skin inspections with PBFD (Sa et al. 2014), and a recent genetic study showed that this disease is now common among various RRP worldwide, which has probably transmitted via the pet trade and includes wild RRP in the tropical islands of Mauritius and Seychelles (Fogell et al. 2018). Field studies show that wild parrots in native ranges are free from several diseases such as Psittacid herpes virus and for antibodies to paramyxovirus serotypes 1 and 3 and internal parasites (Stone et al. 2005). Parrots are not competent hosts for West Nile virus and thus probably could not serve as functional carriers or sources of this virus (Komar et al. 2003). That said, RRP accept food from residential bird feeders (Clergeau and Vergnes 2011, S. Matsunaga, pers. comm., N.P.K., pers. obs.), which enables disease exchange from direct physical contact with dozens of other bird species and their fecal material. An additional behavior of RRP that may aid in disease transmission is their defecation on agricultural crops while foraging on them, and beneath communal roost sites.

The extent to which RRP are disease carriers on Pacific islands is unknown. The only wild RRP in the Pacific that were screened for disease that we are aware of are those by Gaudioso et al. (2012) on Kaua'i where 15-18 individuals were tested and found negative for avian Psittacosis and avian influenza virus. Through physical inspection of recently harvested RRP on Kaua'i (Shiels et al. 2018), and observations of live-birds at bird feeders, evening roosts, and nest cavities in Honolulu (N.P.K. unpubl. data), there was no physical evidence of disease-like symptoms. However, a wild RRP in Honolulu, Hawai'i, was recently observed with symptoms of avian pox or PBFD (Figure 5). Several red-vented bulbuls (Pycnonotes cafer) that shared the same perching trees as the parakeet also had mucosal lesions along the gape and nares (N.P.K., pers. obs.). Naturalized, wild-living non-native parrots elsewhere exhibited 

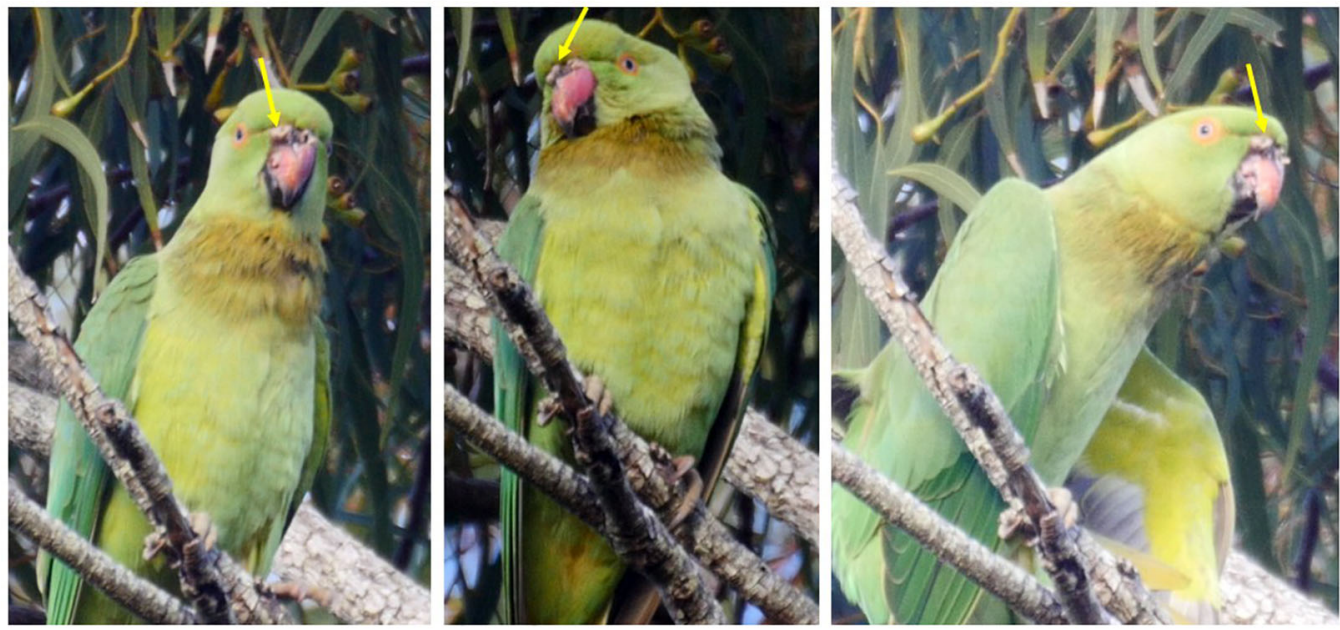

FIGURE 5. A wild rose-ringed parakeet with signs of either avian pox disease or Psittacine beak and feather disease (specific virus confirmation requires PCR genetic screening) in Honolulu, Hawai'i. Notice wart-like growths at the base of the beak (yellow arrows inserted). Both avian pox and Psittacine beak and feather disease can be spread between wild and captive birds, among bird species, and can be lethal to birds. Photographs by N.P.K. in January 2019.

similar symptoms in a location where they interacted with caged birds suffering from the same affliction (Kalodimos 2013). In contrast to the findings in Hawai'i, Mase et al. (2001) isolated avian influenza (H9N2 influenza A virus), which has the potential to be directly transferred to humans, from respiratory organs of RRP that had been imported from Pakistan to Japan, and were very similar (>97\% match) to the influenza strain found in the 1997 human influenza outbreak in Hong Kong. Mase et al. (2001) further concluded that avian influenza may be circulating in RRP distributed through the pet trade. Pet RRP held in captivity also present the possibility of introducing other diseases into populations established in the wild, and this appears to be the case with PBFD in many countries worldwide where wild RRP have established (Fogell et al. 2018). Although confirmed cases of disease in RRP in Hawai' $i$ or other Pacific islands have been absent (but see Figure 5), the potential interaction of wild RRP with captive or wild birds should be viewed as a serious disease transmission concern (e.g., Fogell et al. 2018).

\section{PERCEIVED BENEFITS}

RRP are colorful birds of tropical origin and this can bring an exotic or otherwise favorable feeling towards their local establishment in urban environments by some human residents, as has been the case with some European locations (Menchetti et al. 2016, Crowley et al. 2019) and appears to be so in Hong Kong (M. Leven, pers. comm.). Parrots are generally perceived as intelligent birds with lively characters. Additionally, RRP visitation to backyard birdfeeders in Europe (Butler 2003, Clergeau and Vergnes 2011), O'ahu (N.P.K., pers. obs.), and Japan (Matsunaga, pers. comm.) can be welcomed by some human residents even if they are aware that the birds are nonnative. Such welcoming of these birds outside their native range can make their removal and management extremely difficult (Menchetti et al. 2016, Novak 2018, A.B.S., pers. obs.).

Although some may suggest that RRP have the beneficial effect of reducing non-native plant spread by their high levels of seed predation, such perceived benefits of the RRP are unlikely to be true or at least fall short of 
eliminating weedy plant reproduction entirely. For example, RRP flocks on O'ahu exhibited daily foraging on strawberry guava (P. cattleianum), with each bird in a flock killing 100 or more seeds per feeding (N.P.K. unpubl. data). However, there is no evidence suggesting that RRP kill all of the seeds in a stand or otherwise limit the spread of such a highly invasive plant. Additional species of non-native weedy plants that have been observed having their seed crops significantly reduced by RRP in Hawai'i, yet continue to thrive and spread, include yellow guava $(P$. guajava; Shiels et al. 2018), and high yielding Fabaceae such as Prosopis pallida, Acacia formosa, and F. moluccana (N.P.K., pers. obs.). Because RRP are not known to colonize or forage in continuous native forest, which is where non-native plants are most unwanted, it is unlikely that RRP will help reduce the nonnative plant problems that are nearly ubiquitous in some island settings in the Pacific, such as in the Hawaiian Islands.

Field studies in native habitats have determined that many parrot species may provide pollination services (Skutch 1983, Vicentini and Fischer 1999, Cotton 2001). However, RRP interaction with flowers of species present on Pacific islands generally leads to destruction or partial dismemberment of the flower.

There is a possibility for human economic gain with RRP in the pet trade industry, but markets appear quite saturated and the import and sale of RRP is prohibited in some areas such as the Hawaiian Islands (Hawaii Department of Agriculture statement in 2016 newspaper article: https://www.13abc.com/home/ headlines/Parakeet-problems-at-Hawaii-park365537961.html). Avery and Shiels (2018) presented the RRP import data into the U.S. from 1980 to 2009, which showed imports had peaked at $>40,000$ birds during 1985-1990. Despite widely practiced captive breeding of RRP, wild capturing of RRP in their native range for subsequent sale to the pet trade industry still occurs (Menchetti et al. 2016). In fact, Scalera (2001, cited in Menchetti et al. 2016) reported up to 5,000 RRP were caught each day in Northern India and were sold wholesale to the pet industry for about US\$1 each. Although this has apparently helped reduce RRP abundance and therefore damage in parts of their native range (Scalera 2001), it is facilitating the global dispersal of this potential pest species. It should be emphasized that the reason RRP have invaded islands, countries, and ecosystems outside their native range is due to escaped individuals from the pet trade; therefore, this industry should not be supported for these birds.

\section{REGULATORY ASPECTS}

Regulations on the importation and possession of RRP differ depending on state and country laws. In Hong Kong, Japan, and New Zealand, there appear to be no restrictions on the breeding or sale of RRP, but technically it is prohibited to release them into the wild in New Zealand (N. Mihi, pers. comm.) and they are unwanted organisms under the New Zealand Biosecurity Act (C. Miskelly, pers. comm.). All birds in Hong Kong are protected by law, and therefore RRP cannot be harmed, trapped, killed, or harassed (M. Leven, pers. comm.). RRP in the State of Hawai'i are officially classified as injurious wildlife (DLNR 2014), pestiferous (Koopman and Pitt 2007), invasive (Lohr 2012), and their import into the State (i.e., all Hawaiian islands) has the designation of 'restricted - for private and commercial use' http://hdoa.hawaii.gov/ pi/pq/import-program/). Interestingly, RRP are not on the 'prohibited list' for animal importation into the State of Hawai' $i$, perhaps because they are allowed in some cases such as for research animals or for zoos (http://hdoa. hawaii.gov/pi/pq/import-program/), or because the online importation lists have not been updated since 2006. Furthermore, a 2016 Hawai'i news article quoted a Hawai'i Department of Agriculture employee saying RRP are banned for importation as pets (https:// www.13abc.com/home/headlines/Parakeet-pro blems-at-Hawaii-park-365537961.html), and pet store owners in Hawai' $i$ have confirmed that they are not allowed to sell RRP in Hawai'i (various pet store employees in 2019, pers. comm. with A.B.S.). Although RRP are classified as injurious wildlife in the State of Hawai'i, 
manipulation of this species in the wild is controlled by State law and a special permit is necessary to take, harm, capture, or harass RRP (http://dlnr.hawaii.gov/dofaw/permits/). Landowners on Kaua ' $i$ have applied and subsequently received temporary State permits to shoot RRP that are damaging their crops or property (A.B.S., pers. obs.).

\section{GEOGRAPHIC DISTRIBUTION AND HISTORY}

The RRP has formed reproducing populations in at least 40 countries (Strubbe and Matthysen 2009a), which has earned it classification as the most successful naturalized parrot in the world. Some of the island nations outside of the Pacific for which RRP have naturalized include those in Spain, Portugal, Greece, United Kingdom, Mauritius, Seychelles, Singapore, and Tanzania (Strubbe and Matthysen 2009a, Menchetti et al. 2016). On Pacific islands, RRP were first introduced in Hong Kong in 1903 (Leven and Corlett 2004) and Hawai' $i$ in the 1930s-1960s (Avery and Shiels 2018); RRP have established in the southwestern part of Tokyo, Japan, since 1969 (Gordenker 2009), and in New Zealand first in 2005 where they have been repeatedly established and removed (Miskelly 2018; L. Maria, pers. comm.). In all cases that we are aware of, RRP were introduced into the wild through intentional or accidental release of captive or pet birds. Wild parrot species were imported to many countries in large numbers to be sold as pets in the 1960s through 1980s (Traffic 1987, Collar 1997), yet the pet trade continues to supply RRP to most countries of the world (Menchetti et al. 2016, Avery and Shiels 2018). RRP have continued to be a relatively inexpensive small parrot species that have been readily available in the global pet trade.

In Japan, established RRP are currently only known on the largest island, Honshu. RRP originated from escapees (Eguchi and Amano 2004), and have been known to successfully reproduce in Tokyo, Chiba, Kanagawa, Aichi, Kyoto, and Hiroshima prefecture (region). Additional areas of Honshu Island where RRP have been recorded include Niigata, Tochigi, Gunma, Saitama,
Nagano, Shizuoka, Gifu, Osaka, and Hyogo. In the past, RRP have been recorded in Ehime on Shikoku Island, and further south in Saga and Miyazaki prefecture on Kyushu Island. Apparently, there have been few records recently except for within the Kanto District, which includes Tokyo and its surroundings (Gordenker 2009). Currently (in 2018), there are three surviving groups of RRP in Japan, and they are restricted to: (1) Tokyo, Kanagawa prefecture, and Saitama prefecture ( $>1500$ individuals), (2) Gunma prefecture ( $<50$ individuals), and (3) Chiba prefecture (<20 individuals; S. Matsunaga, pers. comm.).

In New Zealand, RRP have repeatedly established and in most cases have been subsequently removed since 2005 in the North Island (Takapuna to Havelock North), and one population in Christchurch (South Island) was released in 2016 and is still being managed today (Miskelly 2018; L. Maria, pers. comm.). Miskelly (2018) has summarized the incidences of RRP in the wild from the North Island as: breeding and later eradication of RRP occurred in Beachland (South Auckland) in 2005-2006; Okere Falls, Rotorua, had five birds including a fledgling from 2007 (eradication attempted in 2012 but birds still present in 2015); Havenlock North from 2010 (eradication attempted in 2016); Tamahere, Hamilton had at least two birds in 2013; Hikutia, north of Paeroa, had at least 15 birds from 2011 to 2014, and 12 of these were removed in 2014-2015; and Takapuna had four birds in 2015. On the South Island in Christchurch, there was a fire at a zoo in 2016 causing 30 birds to be released and not all were recaptured (Miskelly 2018; L. Maria, pers. comm.). An update in 2018 has confirmed that the Christchurch birds had been successfully breeding in the wild since 2016 and a trapping and shooting program had not successfully removed all of them yet (L. Maria, pers. comm.). Similarly on the North Island, escaped RRP have been removed from the wild except for a few birds surviving an eradication attempt in Havenlock North, Hawkes Bay (L. Maria, pers. comm.).

In Hong Kong, RRP were recorded throughout the territory during the 1970s and $1980 \mathrm{~s}$ in flocks of up to 87 birds. 
However, the RRP population substantially declined and has become restricted to two urban areas on Hong Kong Island, and a third subpopulation is in Kowloon, which is on the mainland-China portion of Hong Kong (Leven and Corlett 2004). Currently there are an about $15 \mathrm{RRP}$ on Hong Kong Island (M. Leven, pers. comm.), separated into two subpopulations (centered on Hong Kong Park, and centered on Ap Lei Chau/Ocean Park). The Kowloon population has about 10 birds, and the population appears to be increasing at the Kowloon roost (M. Leven, pers. comm.). The cause for the decline from the 1980s to present is unknown, and all birds are protected by law in Hong Kong. According to the Hong Kong Bird Report, the significant entries since 1999 stated that the RRP abundance "appears to be continuing to decline" in 1999-2000, and there were multiple entries during 2009-2015 stating their presence on Hong Kong Island (M. Leven, pers. comm.).
In the Hawaiian Islands, RRP are common on Kaua'i and O'ahu (Avery and Shiels 2018), and there is a small (perhaps incipient) population on Hawai'i Island in the Puna District (I. Leinbach, pers. comm.). All RRP in the Hawaiian Islands occupy lowland habitats disturbed by humans (Figure 6). Kaua'i Island has the largest population of RRP, with a minimum number identified in early 2018 of $\sim 6,800$ individuals (A.B.S., unpubl. data); they occupy the southern portion of the island, from Kekaha to Linhu'e, but have been sighted in almost all lowland habitats along the perimeter coast (Figure 6). There are currently two known RRP roosts on the island that each span approximately $1 \mathrm{~km}$; the highest density roost is in the LawwaiPo'ipū-Kōloa area, and second highest density roost is in Lihu'e (Shiels et al. 2018). The origin of the Kaua'i population is believed to be the individuals released by workers at a bed-and-breakfast inn near Lāwai in the 1960s (Pyle and Pyle 2017). By 1981, RRP were
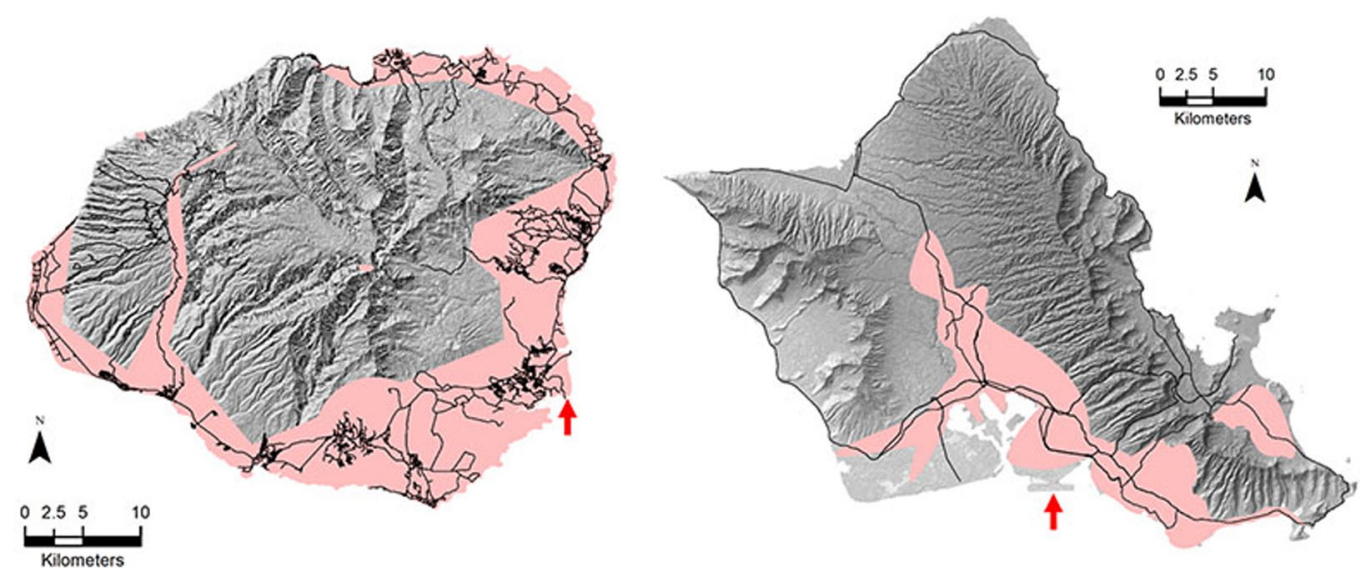

FIGURE 6. Rose-ringed parakeet (RRP) distribution maps for the Hawaiian islands of Kaua'i (left island) and O'ahu (right island), as of June 2019. The pink shading is where RRP have been recorded in the wild, according to observations posted on eBird (https://ebird.org/home) or by authors A.B.S. and N.P.K. The black lines on the maps are major roads, and the two red arrows point to the main airports on each island (Līhu'e Airport on Kaua'i, and Honolulu International Airport on $\left.\mathrm{O}^{\prime} \mathrm{ahu}\right)$. The distance from Kaua'i to $\mathrm{O}^{\prime} \mathrm{ahu}$ is about $115 \mathrm{~km}$, and RRP have never been recorded flying between these islands. 
regularly reported foraging in Hanapēpē Valley and roosting in Kalāheo, just west of Lāwai. Following crop damage in Hanapēpē Valley and permits issued to some residents for RRP lethal control, the birds abandoned their Kalāheo roost and were frequently observed south of Lāwai at the National Tropical Botanical Gardens and east at the Waita Reservoir near Kōloa (Pyle and Pyle 2017). By 1997, the RRP on Kaua'i were well established from Hanapēpē to Līhu'e, with roosts in 'Ōma'o, Kalāheo, and Līhu'e (Pyle and Pyle 2017). By 2012, there were two large roosts (Lāwai-Po'ipūKōloa and Līhu'e), with a combined total of about 2,000 birds counted (Gaudioso et al. 2012), and by 2015 the Kaua'i RRP distribution had extended further west, spanning from Kekaha to Līhu'e (Shiels et al. 2018).

On O'ahu, RRP absolute numbers $(\sim 4,650$ individuals) are less than on Kaua' $i$ and there are at least three population centers (evening roosts: Olomana, Waikele, and Honolulu) widely distributed across the southern and central portion of the island (N.P.K. unpubl. data; Figure 6). RRP were first released into the wild on O'ahu as early as the 1930s, but were not consistently and repeatedly observed until the 1970s (Pyle and Pyle 2009). The early reported centers of abundance on $\mathrm{O}^{\prime}$ ahu in the 1970s were in the Makiki-Punahou areas and Waimānalo areas (Pyle and Pyle 2009); local numbers continued to grow in these areas through the 2000s. In 2000, the Central Union Church in downtown Honolulu had 75 RRP roosting at night (Pyle and Pyle 2017), and that roost now has expanded to about 2,600 individuals and spans approximately $0.5 \mathrm{~km}$ (N.P.K. unpubl. data). Besides this Honolulu roost site, the other active roosts in 2018 on O'ahu were at Olomana Golf Links and Waikele (N.P.K. unpubl. data).

RRP on Kaua'i and O'ahu have strong population growth (see text below, and population growth figures) though there is less known about population trends and distributions on Hawaici Island. Paton et al. (1982) observed a flock of five RRP in eastern Hawai'i Island $(10 \mathrm{~km}$ south of Hilo), and a pair of those subsequently nested in a cavity of a native 'ōhi'a tree (Metrosideros polymorpha) in February 1981. Additionally, there was a flock of 25-30 RRP reported in 1988-1990 in Kona (western Hawai'i Island), and that population had apparently decreased substantially by 2016 and are not considered established by Pyle and Pyle (2017). RRP are currently uncommon and rarely seen on Hawai' $i$ Island; it is speculated that fruit and nut farmers have been lethally shooting them there, which may explain the sparse or lack of sightings in recent times (Pyle and Pyle 2009). On Maui Island, a few RRP have been noted in the wild since the 1980s, but they have not established on this island, including the two escaped RRP observed in Makawao in 1988, one in Wailua in 1990, and one in Nāpili Bay in 2014 (Pyle and Pyle 2017).

Because parrots are generally non-territorial, social, flocking birds, increasing population sizes does not initially promote range expansion (Butler 2003). In England where RRP now number in the many thousands (e.g., ca. 10,000 in 2004, Butler 2005; ca. 30,000 in 2011, Butler et al. 2013), their geographic expansion was minor $(0.4 \mathrm{~km}$ per year) through year 2000 (Butler 2003). Searching for nest cavities is a main driver of parakeet geographic expansion and once a cavity is occupied by a pair, foraging activities are conducted around it (Strubbe and Matthysen 2009a). Food availability can also influence range dynamics, and Matsunaga and Fujii (2018) have observed RRP near Tokyo alter their distribution seasonally to capitalize on preferred food resources.

\section{HABITAT AND CLIMATIC REQUIREMENTS}

RRP exist over a very wide climatic and latitudinal range (ca. $56^{\circ} \mathrm{N}$ to $44^{\circ} \mathrm{S}$ ), and are thus considered to be generalist species. Their native geographic region includes cool habitats in Afghanistan and northern India in the Himalayas to hot and dry savannas and parkland south to Sri Lanka (Juniper and Parr 1998). In their native Indian range, RRP inhabit mesic to semi-arid deciduous and evergreen open forest and savannah. They typically shun dense forest and elevations greater than approximately $1,000 \mathrm{~m}$, yet Menchetti et al. (2016) stated that they can be found up to $2,000 \mathrm{~m}$ elevation. Their presence is often associated with human modified environments such as residential areas, 
parkland, and agricultural land. Commensalism with humans is believed to enhance the probability of an introduced species becoming established (Lockwood 1999, Cassey 2002), and RRP thrive in human-altered landscapes (Strubbe et al. 2015, Shiels et al. 2018).

On each of the Pacific islands where RRP have established, they are active in habitats modified by humans. RRP populations center around suburban and human created parkland, which typically has large ornamental trees used as food, perching, and nesting sources. Like in India, RRP on islands are not highly attracted to closed canopy, dense forest, or exceptionally dry habitats that lack many trees for nesting or foraging (N.P.K., pers. obs.). On both Kaua'i and O'ahu, RRP are most commonly seen in lowland mesic areas of open suburban forest, parkland, farmland, and residential areas up to around $500 \mathrm{~m}$ elevation (Gaudioso et al. 2012, N.P.K. unpubl. data; Figure 6). Knowledge of the spatial organization and proximity of RRP to agricultural plantings is paramount in evaluating RRP risk to agriculture, and predictive niche- and spatial-modeling can help identify areas most at risk of RRP population spread and habitat usage over time.

The range of climates that this species can survive in is broad (temperate to tropical), but it does have limitations. RRP cannot survive in geographic locations where there are prolonged periods of freezing temperatures. RRP introduced into New York City (U.S.A.) suffered from frostbite during the winter (Roscoe et al. 1976), inhibiting their establishment. Similarly, RRP introduced into Belgium have been known to suffer mortality due to winter weather (Temara and Arnhem 1996). Following a European survey, Strubbe and Matthysen (2009c) determined that RRP establishment success declines with decreasing temperature.

\section{RESOURCE REQUIREMENTS AND}

\section{LIMITATIONS}

\section{Nesting Cavity Resource}

The availability of suitable nesting cavities strongly influences the presence of RRP in an area. RRP are secondary cavity nesters and exclusively rely on pre-existing hollows for nesting, though they commonly widen the existing cavity by picking with their strong bill. RRP prefer large diameter trees for nesting rather than randomly sampled trees (Tayleur 2010). RRP often re-use the same cavities in subsequent years. Bluekens (2002) determined cavities were re-used at a rate of $61-70 \%$ during a 3 -year study in Europe. On $\mathrm{O}^{6} \mathrm{ahu}$, the same tree cavities are used each year, but it is not known if it is the same breeding birds using the same cavities from year to year. RRP in their native range nest in tree cavities in many different forest habitats as well as occasionally nest in cavities in roofs or rock walls when suitable tree cavities are not available (Forshaw 1989, Juniper and Parr 1998). In the Hawaiian Islands, RRP are only known to nest in tree hollows (Figure 7);

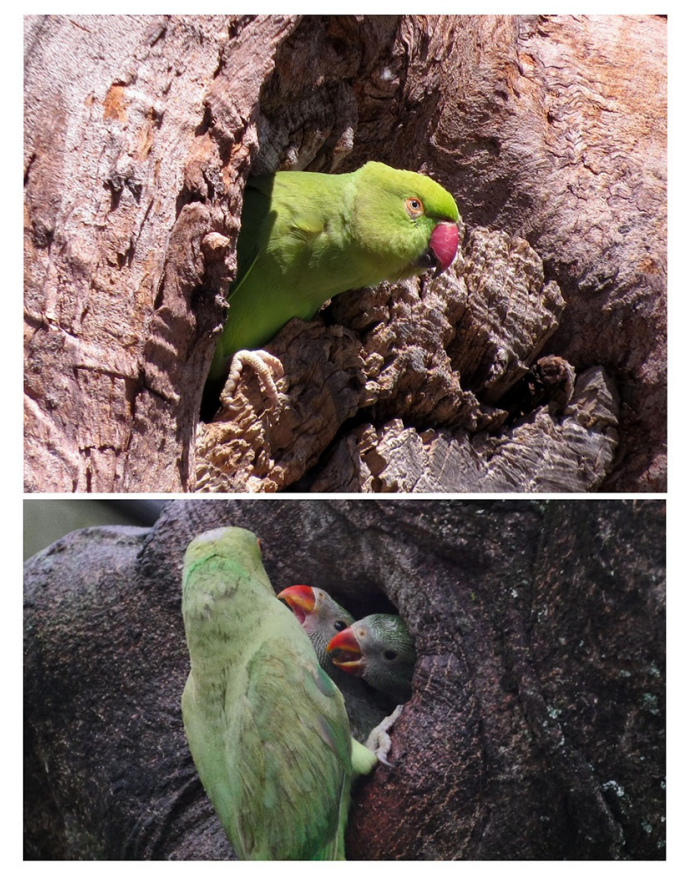

FIGURE 7. Rose-ringed parakeet at nest cavity. Upper picture is an adult female or juvenile of either sex (notice lack of dark ring around neck distinct to adult males) emerging from a nest cavity in an ironwood tree (Casuarina equisetifolia) adjacent to Kapi'olani Park, O'ahu, Hawai'i (Photograph by Phil Taylor). Lower picture is an adult female returning to her nest to feed her young (two of the three chicks are pictured) on $\mathrm{O}^{6} \mathrm{ahu}$, Hawai'i (Photograph by N.P.K.). 
however, these birds have been observed investigating building ventilation, roof drainage holes, and highway viaduct drainage pipes (N.P.K., pers. obs.). Tree cavities used by this species for nesting in the Hawaiian Islands are most commonly ironwood (Casuarina equisetifolia; Figure 7), albizia (Gaudioso et al. 2012), African tulip (Spathodea campanulata) monkeypod (Samanea saman), and silk oak (Grevillea robusta); on one occasion on Hawai' $i$ Island they were found nesting in a cavity of the native 'ōhi'a tree (Paton et al. 1982). Successful nesting appears to occur in cavities $5 \mathrm{~m}$ or higher (N.P.K. unpubl. data). Multiple pairs often nest in the same tree if it has multiple tree hollows. Cavities are focal points for flock socialization, courtship, seasonal pair formation and pairs often compete for nest cavities (Figure 1); fierce fights between RRP when choosing their nest cavities can be observed (Bluekens 2002). The lack of available (unoccupied) cavities in an area likely motivates pairs to explore new geographic areas for usable cavities, as nesting cavities are a limited resource for RRP (Bluekens 2002, Strubbe and Matthysen 2007).

\section{Food Resource}

The presence of not only nesting resource but also food species is important for RRP presence (Matsunaga and Fujii 2018). Trees with legume seed crops such as Prosopis spp., Ceasalpinia spp., Pithecellobium dulce, and Cassia spp., as well as other seed crops including a few with fleshy pulp such as Terminalia spp., Livistona chinensis, and Mangifera indica appear to be indicative of areas this species frequents on a daily or weekly basis on O'ahu (N.P.K., pers. obs.). Guava and corn comprised the majority of the RRP diet on Kaua' $i$, and corn is planted year-round so this food resource is readily available (Shiels et al. 2018). Matsunaga and Fujii (2018) have suggested that the RRP distribution shifts around Tokyo according to availability of food resources, including nectar sought from several species of flowering trees. In temperate areas where this species has naturalized (e.g., Japan, California, England, Netherlands, Belgium, Germany), RRP appear to partially rely upon food from bird feeders, especially during the winter months (Garrett et al. 1997, Bittner 2008, Clergeau and Vergnes 2011, S. Matsunaga, pers. comm.). During a radio-tracking study in suburban France, Clergeau and Vergnes (2011) determined that approximately half of the foraging time of RRP was at residential bird feeders, and the availability of this constant anthropogenic food source could be a key to its success in the region. On O'ahu, RRP also use bird feeders, but they do not rely upon them for survival (N.P.K., pers. obs). Water sources are undoubtedly important and may influence this species' strong affinity for mesic environments where it can access water resources from pooled water in the canopy, or from flowers or fruit in trees. RRP have not been seen to descend to the ground in the Hawaiian Islands despite this being a regular occurrence in Japan (Matsunaga and Fujii 2018) and France (Clergeau and Vergnes 2011). Artificial feeding of RRP should be discouraged especially in areas that do not yet have RRP but are near a RRP population; it only takes a few birds to find a food source and more will quickly follow.

\section{DEMOGRAPHY}

\section{Reproduction and Aging}

The breeding biology of the RRP on the Indian sub-continent is well known, though it is poorly known on Pacific islands. In southern India, RRP begin nesting as early as December while in northern India they begin nesting in February (Lamba 1966, Shivanarayan et al. 1981, Forshaw 1989, Juniper and Parr 1998). Clutch size ranges from two to six eggs (Lamba 1966, Shivanarayan et al. 1981), with the median being four eggs, two of which are generally fertile (Lambert et al. 2009, Tayleur 2010, Butler et al. 2013). RRP spend a total of 9-10 weeks in the nest: 3 weeks incubating eggs, and 6-7 weeks feeding the young (Lamba 1966, Shivanarayan et al. 1981, Forshaw 1989, Juniper and Parr 1998). In their Indian range, RRP enjoy a relatively high rate of breeding success. Lamba (1966) examined 33 nests and found that an average of 3.0 young fledged per nest. Shivanarayan 
et al. (1981) examined 66 nests and found that an average of 1.7 young fledged per nest. This lower reproductive success was attributed to predation by crows and snakes (Shivanarayan et al. 1981). In England, Butler (2003) studied 108 RRP nests during 2001-2003 and confirmed that fledging rates averaged $1.9( \pm 0.1$ SE) young per nest. Twelve RRP nests inspected in the Greater London area during 1997-1998 revealed an average of 0.8 young fledged per nest (Pithon and Dytham 1999). On O'ahu, nesting begins uniformly about the middle of January and the chicks fledge during the first half of April (N.P.K, unpubl. data). Only a single clutch is raised though reclutching is possible if eggs are lost early in the incubation period (Lambert et al. 2009). During the 2012 and 2013 breeding seasons, out of seven nests on $\mathrm{O}^{\prime}$ ahu there was an average fledgling success rate of 3.0 chicks per nest with each pair producing two to four fledglings (N.P. $\mathrm{K}$, unpubl. data). RRP Reproduction rates on other Pacific islands are unknown aside from evidence from one nest cavity on Hawai' $i$ Island containing four eggs that resulted in just one fledgling (Paton et al. 1982).

RRP are known to reach maturity at about 1.5 years old, which is prior to acquiring their mature plumage pattern (Butler 2003). Adult plumage is usually complete at about $2-2.5$ years of age (Butler 2003). Senar et al. (2019) followed 156 wild RRP for 13 years in Barcelona, Spain, and estimated annual survival probabilities for adults (0.83, 95\% confidence interval $[\mathrm{CI}]$ : $0.77-0.87)$ and juveniles during their first $(0.57,95 \% \mathrm{CI}$ : $0.37-0.79)$, second (0.79, 95\% CI: $0.58-0.87)$, and third winter (0.83, 95\% CI: $0.65-0.88)$; adult females had slightly higher survival (0.87, 95\% CI: $0.78-0.93)$ than adult males (0.80, 95\% CI: 0.73-0.86). Average life-span of these wild RRP was estimated as 4.8 years (95\% CI: 3.6-6.4 years), although one bird was 12 years old and one was 14 years old at the end of the study. In captivity, RRP generally live for 20 years (Pithon 1998) and may live for as long as 34 years (Brouwer et al. 2000). RRP do not maintain strong pair bonds outside of the breeding season and it is not clear if pairs consist of the same partners from year to year.

\section{Population Dynamics}

A repeated pattern for RRP introductions is that there appears to be a pronounced lag time between initial introduction and before a rapid and exponential population increase. For example, RRP temporarily established in the U.K. in 1855, and it took $\sim 140$ years to establish a self-sustaining population (Lever 1987, Tayleur 2010). The lag time from initial introduction to rapid and exponential increase was $\sim 40$ years on Kaua'i and $\sim 70$ years on O'ahu (Figure 8). Many factors can influence lag times and examples of the Allee effect (e.g., number of individuals introduced and maintained, number of introduction events, male to female ratio, available resources; Lockwood et al. 2007). In the lag time years, RRP populations appear to fluctuate and may even temporarily decrease in some years. Established RRP populations on both Hong Kong Island in the 1980s and 1990s (Leven and Corlett 2004), and Honshu Island recently (S. Matsunaga, pers. comm.), showed significant reductions over several years despite an absence of any population control of the birds by humans. Aside from the well-established RRP populations on the islands of Kaua'i, O'ahu, and Honshu that each have $>1,000$

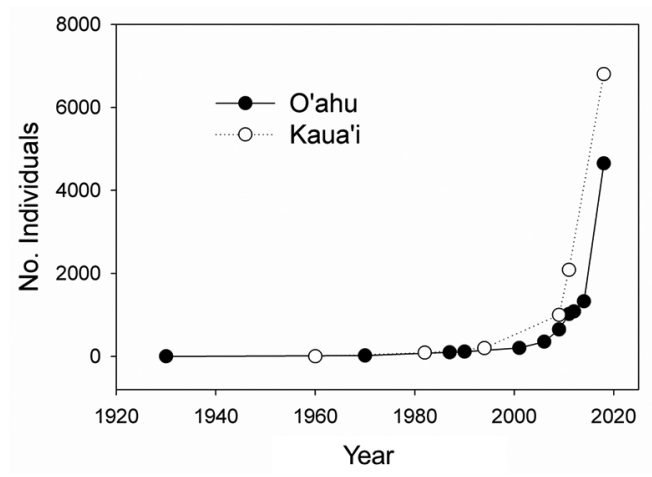

FiguRE 8. Rose-ringed parakeet (Psittacula krameri) population estimates of established birds in the wild on O'ahu (1930-2018), and Kaua'i (1960-2018). Estimates are minimum number known alive based on visual surveys. The pre-2012 (O'ahu) and pre-2010 (Kaua'i) data points were reported by Pyle and Pyle (2017) using Bishop Museum records, and the 2012-2018 counts were by author N.P.K. (O'ahu) and the 2011 and 2018 counts were by author A.B.S. (Kaua'i); see text for methods description. 
RRP, the remaining islands in the Pacific with established RRP have highly fluctuating populations as a result of management (New Zealand) or presumably natural causes (Hawai'i, Hong Kong; Table 1). Furthermore, Kaua' $i$ and O'ahu are the only two islands in the Pacific with recent and regular island-wide population estimates during the last 6-12 years.

Kaua' $i$ has the largest population of RRP in the Pacific. The first birds introduced into the wild were in the 1960s, and by 1982 the population had grown to 90 birds (Pyle and Pyle 2017). By 1994, late 2000s, and 2011, the population was estimated at 150-200 birds, 500-1,000 birds, and over 2,000 birds, respectively (Gaudioso et al. 2012, Pyle and Pyle 2017). The most recent count of RRP in January 2018 on Kaua'i was 6,801 birds (A.B. S., unpubl. data; Figure 8); therefore, the RRP population on Kaua'i more than tripled within 6 years and experienced an average annual growth rate of $22.5 \%$. Whereas the count at each of the two roosts on Kaua'i (LāwaiPo'ipū-Kōloa and Līhu'e) was nearly evenly split in December 2011 (Gaudioso et al. 2012), the Lāwai-Po'ipū-Kōloa roost accounted for two-thirds of the birds on the island in 2018 (A.B.S., unpubl. data). A brief description of the methods that A.B.S. used in 2011 and 2018 to count the RRP population on Kaua' $i$ are summarized here. RRP at the two roosts (Lāwai-Po'ipū-Kōloa and Līhu'e) were counted during the same week, and by the same observer (A.B.S) in December 2011 (see Gaudioso et al. 2012) and January 2018. Each RRP count occurred at dawn (06000715 hours), as individuals began to leave the roost area, until the last individual left the roost. As in Gaudioso et al. (2012), and from a vantage point nearby the roost (generally in the direction the birds flew, which was north or inland towards the mountains), RRP were counted individually, but if flock size was large ( $>50$ individuals) RRP were counted in increments of five birds. During the 2018 count at the Lāwai-Po'ipū-Kōloa roost, the observer was stationed on the rooftop of a $12 \mathrm{~m}$ tall building east of Lāwai Beach Resort (Làwai Road) to complete the counts on 22 and 24 January; these counts were averaged to produce a single count for this roost. At the Lìnu'e roost, there was a single count on 23 January 2018, and the observer was stationed on the ground, about $40 \mathrm{~m}$ northeast of the backside of the Historic County Building (Rice Street), which was the same location as in 2011.

RRP on O'ahu have experienced the same population growth patterns as on Kaua' $i$, yet the $\mathrm{O}^{\prime}$ ahu population is just behind Kaua' $\mathrm{i}$ in timing and total numbers of birds (Figure 8). The current estimate (in 2018) for RRP on $\mathrm{O}^{\prime}$ ahu is 4,557 individuals, of which 2,600 are at the Honolulu roost, 1,723 are at the Waikele roost, and 234 are at the Olomana roost (N.P.K. unpubl. data). The author N.P.K. sampled the Honolulu roost since 2005 using the same sampling techniques during the post-fledging, non-nesting season. Briefly, the sampling method used by N.P.K. was similar to that described above for Kaua'i, but flocks at the Honolulu roost were photographed as they arrived in the early evening, typically 18:30-19:30, depending upon the season, and tallying the birds was subsequently completed using a computer monitor. This sampling of the Honolulu roost yielded an average annual growth rate of $21 \%$ based on roost counts of $181 \pm 56$ (mean \pm SE; $n=3), 213 \pm 63,(n=4), 448 \pm 20 \quad(n=2)$, $1,210(n=5)$ in non-nesting portions of years $2005,2006,2010$, and 2014, respectively. The O'ahu and Kaua'i estimated annual growth rates are similar to that in the U.K. (27\%) estimated by Butler et al. (2013) where RRP totaled 10,000 individuals by 2004 and may now be as high as 30,000 birds (Butler et al. 2013). Upon author N.P.K. counting the Honolulu roost during the incubation nesting phase of 2015, only $789(n=3)$ RRP returned to the nightly colonial roost, meaning about $35 \%$ (or 421 individuals) of the RRP were missing at the nighttime roost compared with roost counts before the nesting season in 2014. The large number of missing birds at the colonial evening roost probably can be attributed to these birds being females that were incubating eggs at their nest sites. When incubating and feeding their young, females remain at the nest day and night despite male mates returning to the colonial roost each 


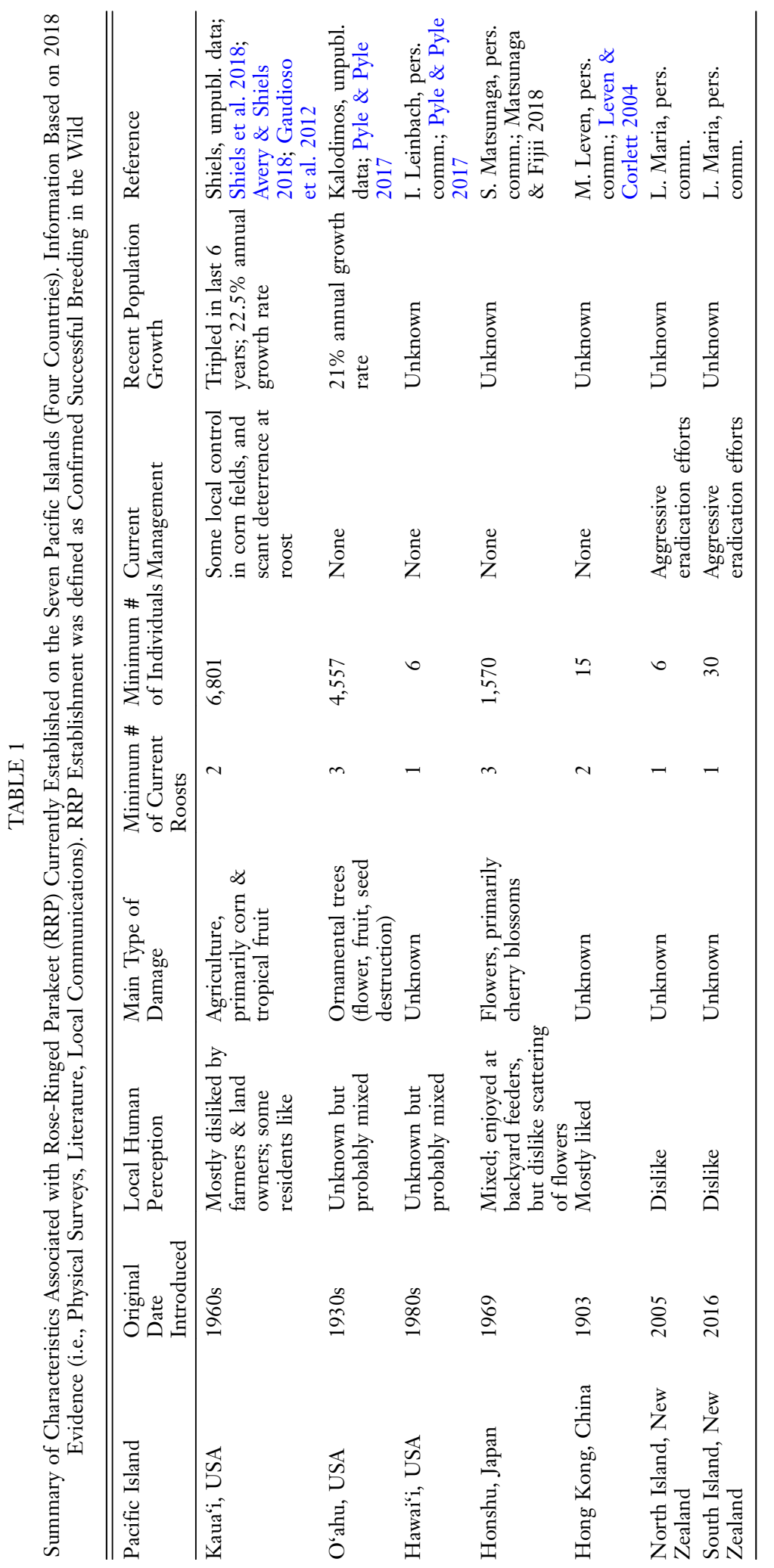


night. This suggests approximately $70 \%$ of the RRP population (male-female pairs) were reproductively active during the 2014-2015 survey; such a high proportion of the population being reproductively active would greatly contribute to the exponential increase seen in RRP populations (Figure 8). RRP are the most numerous, most widely dispersed, and have the most rapid population growth of any parrot species in the Hawaiian Islands.

\section{PREDATORS}

Few effective predators of RRP have been documented on Pacific islands where RRP have established. Birds of prey, such as hawks and owls, would be potential predators of RRP, and observations in Honshu have revealed that northern goshawk (Accipiter gentilis), peregrine falcon (Falco peregrinus), and large-billed crow (Corvus macrorbyncos) have caught and eaten RRP (S. Matsunaga, pers. comm.). In Europe, the main predator of RRP are squirrels (Sciurus spp.), which prey upon the eggs and chicks in the nesting cavities (Mori et al. 2013). Introduced grey squirrels (Sciurus carolinensis) depredated five RRP tree-cavity nests in the U.K. (Butler et al. 2013), and owls (Strix aluco) and raptors (peregrine falcon, Eurasian sparrowhawk [Accipiter nisus], and hobby falcon [Falco subbuteo]) have been documented taking RRP in central London (Hancock and Martin 2015). Common mynas (Acridotheres tristis) are the dominant cavity nester on several Hawaiian islands and these non-native birds overpower RRP for nest cavities as well as potentially depredate RRP eggs and young nestlings in tree cavities (N.P.K., pers. obs.). Feral honeybees (Apis mellifera) have been observed occupying tree hollows and therefore preventing RRP from using cavities for nesting on O'ahu (N.P.K. unpubl. data) and in Europe (Menchitti and Mori 2014). RRP appear threatened by some seabirds, as observed at a RRP evening roost on $\mathrm{O}^{\prime}$ ahu where RRP were taking off in masses and circling in a tight flock in response to overhead-soaring great frigate birds, Fregata minor, and white terns, Gygis alba (N.P.K., pers. obs.).

\section{MANAGEMENT}

The two main management techniques practiced on RRP include population reduction and deterrence. Common deterrents that largely remain untested for their efficacy against RRP include: gas- or audio-cannons, pyrotechnic exploders, hand-held lasers, automated water sprays at canopy roosts, reflectors, mirrors, ribbons, bird of prey or dead RRP effigies, and covering resources with nets (Gaudioso et al. 2012, Khan et al. 2013, Klug et al. 2019). In Pakistan, where RRP commonly eat and destroy fruit trees, Khan et al. (2013) had success deterring RRP using an ultrasonic sound player in the center of fruit orchard fields. The sound player acted as a bird repellent and had audio playback of sounds of "alarming noises of some fearsome animals". Using this technology, RRP visits were reduced by $50 \%$ in yellow guava orchards and $90 \%$ in mango orchards, and apparently the sound player also helped reduce damage to sunflower fields (Khan et al. 2013). Residents near evening roosts on Kaua'i have used hand-held lasers to annoy and scatter the RRP just after they have entered their roost tree (M. Martin, pers. comm.). A common challenge with using any deterrent is that animals can become habituated and therefore the efficacy of the deterrent often decreases over time (Avery and Shiels 2018).

Population reduction or eradication of introduced RRP populations has been challenging, largely due to the difficulty in lethally controlling their populations when they live near humans, the lack of restrictions for their breeding or sale, and the substantial human regard for them in many settings (Crowley et al. 2019). Even when RRP populations are small and all individuals can be removed from the wild on an island, new introductions can easily occur due to RRP maintained as pets and caged birds. New Zealand has lethally managed several incipient RRP populations, removing them quickly after their establishment. In 2015 in Hikutaia (North Island), 12 birds were successfully removed by tracking, trapping, and shooting; in 2016 in Havelock North (North Island), six birds were successfully 
shot and there is a follow-up plan to eliminate the few that were missed; and in 2016 in Christchurch (South Island), about 30 birds were purposefully released from an aviary at a zoo when a fire occurred, and these birds successfully bred over a few years and they are now under a trapping, shooting, and monitoring program (L. Maria, pers. comm.). Of the Pacific islands with RRP currently established (Table 1), it appears that North and South Island of New Zealand are the most likely to be RRP-free in the near future, and this is due to their early, aggressive, and persistent RRP removal efforts.

The only eradication of RRP on islands that we are aware of has recently occurred in the Seychelle Islands, Indian Ocean, summarized by Bunbury et al. (2019). There, 545 RRP were removed from Mahé Island $\left(157 \mathrm{~km}^{2}\right)$, largely by shooting after poor mist-netting success. Of particular importance to this island-wide eradication of RRP was to advertise these efforts and their importance to the local community early in the planning stages. Bunbury et al. (2019) determined that $80 \%$ of the respondents found out about the local RRP problems and eradication efforts through the informational advertisements that were broadcast on television, particularly just before the nightly news. The RRP eradication strategy that worked best was to not disturb the birds at their vulnerable roost sites because that would scatter the population from the very few reliable roost sites, but instead they recommended identifying the flight patterns of the birds returning to roosts each evening and then shooting the birds in strategic locations along the flight paths as they stopped briefly to congregate. Mahé Island is approximately nine times smaller than Kaua'i, and about 10 times smaller than $\mathrm{O}^{\prime} \mathrm{ahu}$, and both of these Hawaiian islands have been informally discussed for RRP eradication but no formal evaluation for significant control or eradications needs has occurred. Significant barriers to replicating the Mahé Island RRP eradication techniques on O'ahu and Kaua'i include the typical RRP flight patterns to roost (particularly on O'ahu) are through residential and urban areas that would make safe and persistent shooting difficult, RRP maintain a high altitude and resting height that is often out of range for shotgun control (particularly on Kaua'i), and relative to the $545 \mathrm{RRP}$ on Mahé Island there are many more RRP on $\mathrm{O}^{\prime}$ ahu $(4,560)$ and Kaua' $i(6,800)$ and these islands are much larger than Mahé.

Because invasive species eradications from islands are not always possible or successful, population suppression is often the next best management practice. Because RRP have few effective predators and long lifespans of 14+ years (Pithon 1998, Senar et al. 2019), the most effective way to reduce population growth is by removing breeding aged birds from the population (Butler 2003). Whereas RRP are protected by law in Hong Kong, there was a period of RRP lethal control in Japan in the 1980s to protect agricultural crops from RRP damage. Approximately 100 RRP were shot in Chiba prefecture to help reduce damage to peanuts being grown in the region (S. Matsunaga, pers. comm.). In the Hawaiian Islands, parrot population reduction has occurred for RRP on Kaua'i and mitred parakeets on Maui. On Kaua'i where RRP are particularly destructive to the seed corn industry that is managed by multinational companies, hundreds of thousands of dollars are spent each year in efforts to reduce crop damage by RRP (Koopman and Pitt 2007). Despite contractors such as USDA APHIS Wildlife Services harvesting a few hundred parakeets each year from corn fields in Kaua'i since 2002, it has had no obvious effect on the island's RRP population (Gaudioso et al. 2012, Avery and Shiels 2018). Additional lethal control methods attempted to reduce the RRP population on Kaua'i have included shooting at their nighttime roost, and live-trapping. Aside from live-trapping attempts, which yielded no catch (Gaudioso et al. 2012), shooting can result in harvests of several birds a day (corn fields) to $\sim 120$ in a night (roosts while RRP are sleeping). On O'ahu, quadcopter drones have been shown to attract perching and undetected RRP in a geographic area to synchronously become airborne, then circle the drone, and eventually mob the drone (A.B.S. and N.P.K., pers. obs.); this may be a method to move large flocks of 
RRP to low altitude locations that are safe for shooting or netting. However, RRP quickly become aware of these flock reduction techniques after just a few days of control efforts and then change their visitation or roosting patterns (W. Bukoski, pers. comm.). As a result of low efficacy of previously attempted RRP damage control methods, corn companies on Kaua'i have recently begun to cover their corn fields with large amounts of netting (Figure 9), which has helped to reduce damage and seed loss.

We know of no attempts to control RRP populations on $\mathrm{O}^{\prime} \mathrm{ahu}$, and the Hawai'i Island RRP population is so small that land managers appear complacent if they even know the population exists. RRP in the coffee growing region of Kona, Hawai'i Island, historically may have been culled by orchard farmers to
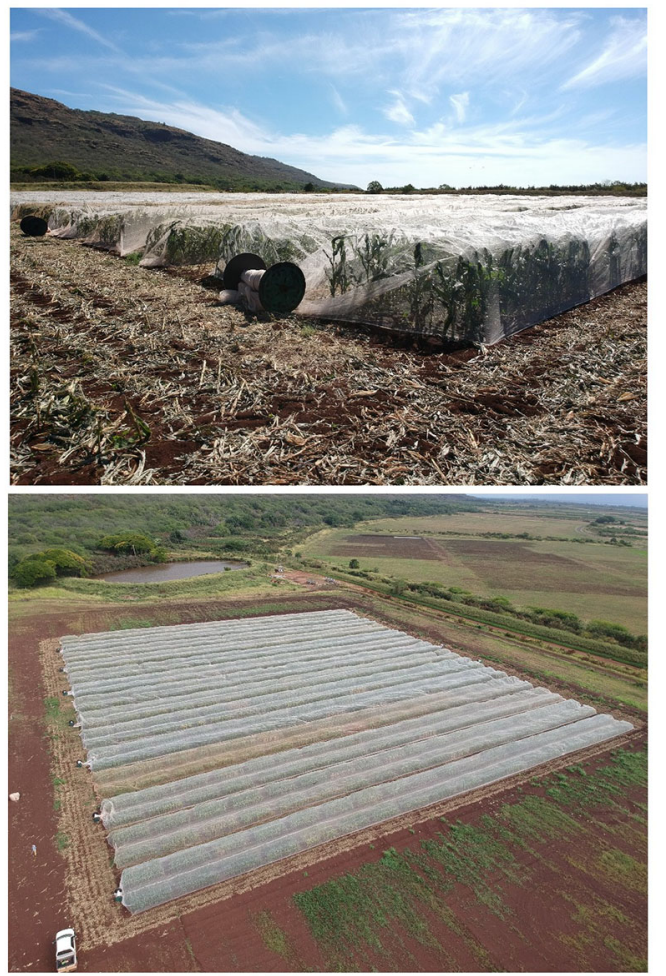

FIGURE 9. Netting is currently used to cover whole fields of corn (Zea mays) on Kaua'i to prevent seed damage and consumption by rose-ringed parakeet (Psittacula krameri). Photographs by Sarah Thompson. safeguard against RRP depredation of coffee fruit and seed. It is unknown if coffee orchard cullings were proactive measures to eliminate the individuals or reactionary measures in response to crop depredations (Pyle and Pyle 2009). Unlike the RRP population, the mitred parakeet population on Maui was reduced primarily via shooting by approximately $85 \%$ (from about 150 to 20 individuals) in 8 years (Radford and Penniman 2014).

The use of toxicants to control RRP has not been tested to our knowledge, despite avian toxicants commonly field tested to control agricultural pests (Linz 2013). Toxicants mixed into an attractive bait-matrix are typically unpopular with the public. Prior to any use of a toxicant, a thorough risk assessment would be needed to ensure effectiveness on RRP and prevent non-target species exposure. There are no known species-specific biological control agents for the RRP, and therefore introducing RRP diseases is not currently a management option. Unlike toxicants, fertility control is a non-lethal method that could be trialed for RRP population reduction. The contraceptive Diazacon has shown success at limiting reproduction of RRP in a laboratory setting in the U.K. when RRP were dosed with $18 \mathrm{mg} / \mathrm{kg}$ of Diazacon for $10 \mathrm{~d}$ (Lambert et al. 2010). Although promising from these laboratory results, Diazacon still requires testing to ensure an attractive formulation and delivery system for RRP, an appropriate dosing frequency, and a risk assessment that accounts for non-target species effects (Avery and Shiels 2018). RRP on Kaua'i could not be drawn to feeding stations or live-decoy traps that were placed in corn fields frequented by RRP (Gaudioso et al. 2012). Therefore, a major barrier to effective use of toxicant or contraceptive bait is successfully drawing RRP into a control device or bait dispensary.

Management actions for RRP are recommended to be focused on specific agricultural fields, locations where they are causing damage, potential nesting areas, and on their flight path approaches to evening roosts. Toxicants or fertility control baits could be deployed in bait stations to reduce or eliminate non-target exposure. Because nest 
cavities are often a limiting resource for RRP, artificial cavities with self-resetting lethality devices inside could be crafted and deployed in attempt to target adult breeders. If RRP are lethally controlled at the roost (e.g., via shooting or large mist nets deployed using long poles or a bucket truck; Avery and Shiels 2018), it is likely that the population will scatter and become more difficult to predict roosting sites and flight routes into roosts (N. Bunbury, pers. comm.). Thus, it is recommended that final evening roosting locations not be used as management locations because birds will desert evening roost sites for months if they feel threatened (Kalodimos 2008) and a level of predictability of population movements will have been lost (Bunbury et al. 2019). Instead of lethal control activities at the roost, it is recommended that the RRP flight patterns on the way to their evening roosts are exploited and RRP are removed along their regular approach to roost.

\section{PROGNOSIS AND RECOMMENDATIONS}

Parrots have loud and persistent vocalizations, gregarious flocking and evening roosting behaviors, and their activity is routine and predictable making detection, monitoring, and management possible and worthwhile. Approximately $16 \%$ of the world's parrot population (60 of 335 species) has established breeding populations outside of their native ranges (Menchetti and Mori 2014); by far the most widespread and damaging of all of these parrot colonist species is the RRP. Given their proven ability to survive in tropical and temperate climates, and from Japan to New Zealand in the Pacific, most human-colonized islands in the Pacific could support RRP populations if they were to become accidentally or purposefully introduced. The likelihood of such introductions is high given the popularity of this species in the pet trade and in zoos and aviaries. Urban areas and agricultural lands at low elevation $(\leq 500 \mathrm{~m})$ are preferred RRP habitats within an island for foraging, nesting, and roosting. Thus, human interactions with these birds are certain once RRP establish, and their aesthetic beauty of bright green plumage and exotic/ tropical feelings that they may bring to some people is expected to diminish as local RRP populations exponentially grow. RRP establishment and population growth generates human complaints and suffering from their loud calls in large flocks, defecation beneath mass-roosting, extreme crop damage, ornamental tree damage, potential predation of native seed plants and spread of non-native seeds, and potential to transfer pathogens to other wildlife and to humans. Therefore, the generally complacent attitude towards RRP establishment outside their native range is, in our view, inappropriate. Instead, aggressive management strategies where action is immediate and science-based, like practiced in New Zealand, is the most responsible way to address new introductions of RRP, and additional science-based management strategies should be employed to reduce and hopefully eliminate large populations like those established on Kaua' $i$ and $\mathrm{O}^{\prime}$ ahu. In particular, local government and biosecurity authorities should take measures to prevent this species from establishing on new islands and in new areas with valued crops, rare plant species that reproduce by seed, and endemic parrot and/or cavity-nesting fauna.

\section{ACKNOWLEDGMENTS}

We are grateful for the local status updates on RRP in 2018 provided by Lisa Maria (New Zealand), Satomi Matsunaga (Japan), Michael Leven (Hong Kong), and Israel Leinbach (Hawai'i Island). We thank Nancy Bunbury, Diederik Strubbe, and two anonymous reviewers for helpful suggestions that improved the manuscript. Findings and conclusions in this publication have not been formally disseminated by the U.S. Department of Agriculture and should not be construed to represent any agency determination or policy.

\section{Literature Cited}

Ali, S., and S. D. Ripley. 1969. Handbook of the birds of India and Pakistan. Vol. 3. Oxford University Press, Oxford. 
Avery, M. L., and A. B. Shiels. 2018. Monk and rose-ringed parakeets. Pages 333-357 in W. C. Pitt, J. C. Beasley, and G. W. Witmer, eds. Ecology and management of terrestrial vertebrate invasive species in the United States. Taylor and Francis, CRC Press, New York.

Bashir, E. A. 1979. A new "parotrap" adapted from the MAC trap for capturing live parakeets in the field. Bird Control Seminars Proceedings, Paper 23.

Bittner, M. 2008. The wild parrots of Telegraph Hill: A love story... with wings. Harmony.

Bluekens, K. 2002. Inleidende studie naar het nestgebruik van halsbandparkieten en de concurrentie met inheemse volgelsoorten. M.S. Thesis. Department of Biology, University of Antwerp.

Brouwer, K., M. L. Jones, C. E. King, and H. Schifter. 2000. Longevity records for Psittaciformes in captivity. Int. Zoo Yearb. 37:299-316.

Bunbury, N., P. Haverson, N. Page, J. Agricole, G. Angell, P. Banville, A. Constance, J. Friedlander, L. Leite, T. Mahoune, E. Melton-Durup, J. Moumou, K. Raines, J. van de Crommenacker, and F. FleischerDogley. 2019. Five eradications, three species, three islands: overview, insights and recommendations from invasive bird eradications in the Seychelles. Pages 282288 in C. R. Veitch, M. N. Clout, A. R. Martin, J. C. Russell, and C. J. West, eds. Island invasives: Scaling up to meet the challenge. Occasional Paper SSC no. 62. IUCN, Gland, Switzerland.

Butler, C. J. 2003. Population biology of the introduced rose-ringed parakeet Psittacula krameri in the U.K. Ph.D. diss., University of Oxford, Oxford.

- 2005. Feral parrots in the continental United States and United Kingdom: past, present, and future. J. Avian Med. Surg. 19:142-149.

Butler, C. J., and A. Gosler. 2004. Sexing and aging rose-ringed parakeets Psittacula krameri in Britain. Ringing Migr. 22:7-12.

Butler, C. J., W. Cresswell, A. Gosler, and C. Perrins. 2013. The breeding biology of the rose-ringed parakeet Psittacula krameri in England during a period of rapid population expansion. Bird Study 60:527-532.

Cassey, P. 2002. Life history and ecology influences establishment success of introduced land birds. Biol. J. Linn. Soc. 76:465-480.

Clergeau, P., and A. Vergnes. 2011. Bird feeders may sustain feral rose-ringed parakeets Psittacula krameri in temperate Europe. Wild. Biol. 17:248-252.

Collar, N. 1997. Family Psittacidae (Parrots). Pages 296-339 in J. del Hoyo, A. Elliott, and J. Sargatal, eds. Handbook of birds of the world. Vol. 4. Lynx Edicions, Barcelona.

Corlett, R. T. 1998. Frugivory and seed dispersal by vertebrates in the oriental (Indomalayan) region. Biol. Rev. Cambridge Phil. Soc. 73:413-448.

Cotton, P. A. 2001. The behavior and interactions of birds visiting Erythrina fusca flowers in the Colombian Amazon. Biotropica 33:662-669.

Cramp, S. 1985. Handbook of the birds of Europe, the Middle East and North Africa. The birds of the Western Palearctic. Vol. IV. Oxford University Press, Oxford.

Crowley, S. L., S. Hinchliffe, and R. A. McDonald. 2019. The parakeet paradox: understanding opposition to introduced species management. J. Environ. Manag. 229:120-132.

del Hoyo, J., A. Elliot, and J. Sardatal. 1997. Handbook of the birds of the world. Vol. 4: Sandgrouse to cuckoos. Lynx, Barcelona.

DLNR. 2014. Hawai'i Department of Natural Resources 2013. Accessed April 2016. http://dlnr.hawaii.gov/dofaw/files/2013/ 09/HAR-13-124-Draft.pdf.

Eguchi, K., and H. E. Amano. 2004. Spread of exotic birds in Japan. Ornithol. Sci. 3:3-11.

England, M. D. 1974. Feral populations of parakeets. British Birds 67:393-394.

Fletcher, M., and N. Askew. 2007. Review of the status, ecology, and likely future spread of parakeets in England. Central Science Laboratory, York, U.K.

Fogell, D. J., R. O. Martin, N. Bunbury, B. Lawson, J. Sells, A. M. McKeand, 
V. Tatayah, C. T. Trung, and J. J. Groombridge. 2018. Trade and conservation implications of new beak and feather disease virus detection in native and introduced parrots. Conserv. Biol. 32:1325-1335.

Forshaw, J. M. 1989. Parrots of the world. Blandford Press, London.

Galetti, M. 1993. Diet of the scaly-headed parrot, Pionus maximiliani, in a semideciduous forest in southeastern Brazil. Biotropica 25:419-425.

Garrett, K. L., K. T. Mabb, C. T. Collins, and L. M. Kares. 1997. Food items of naturalized parrots in southern California. West. Birds 28:196-201.

Gassman-Duvall, R. 2002. Naturalized mitred conures on Maui and other parrots-pest evaluation and management proposal for non-native, invasive bird species. Unpublished draft report, Maui Invasive Species Committee, Makawao, Maui, Hawai'i.

Gaudioso, J. M., A. B. Shiels, W. C. Pitt, and W. P. Bukoski. 2012. Rose-ringed parakeet impacts on Hawaii's seed crops on the island of Kauai: Population estimate and monitoring of movements using radio telemetry. Final report QA 1874, USDA, National Wildlife Research Center, Hilo, Hawai'i.

Gordenker, A. 2009. Feral parakeets. The Japan Times, March 19, 2009: https:// www.japantimes.co.jp/news/2009/03/19/ reference/feral-parakeets/\#.WszUyf4U mot.

Groombridge, J. J., C. J. Jones, R. A. Nichols, M. Carlton, and M. W. Bruford. 2004. Molecular phylogeny and morphological change in the Psittacula parakeets. Mol. Phylogenet. Evol. 31:96-108.

Hancock, R., and J. R. Martin. 2015. Predation of rose-ringed parakeets by raptors and owls in Inner London. British Birds 108:349-353.

Hernandez-Brito, D., M. Carrete, C. Ibanez, J. Juste, and J. L. Tella. 2018. Nest-site competition and killing by invasive parakeets cause the decline of a threatened bat population. R. Soc. Opn. Sci. 5(5):172477.
Jackson, H., D. Strubbe, S. Tollington, R. Prys-Jones, E. Matthysen, and J. J. Groombridge. 2015. Ancestral origins and invasion pathways in a globally invasive bird correlate with climate and influences from bird trade. Mol. Ecol. 24:4269-4285.

Juniper, T., and M. Parr. 1998. Parrots: A guide to parrots of the world. Yale University Press, London.

Kalodimos, N. 2008. Determination of movement and foraging patterns of Aratinga erythrogenys (Aves: Psittacidae) on O'ahu, Hawai'i, using mist-net live capture and radio telemetry. Report to the Division of Forestry and Wildlife, Department of Land and Natural Resources, State of Hawai'i, Honolulu, Hawai'i.

- 2013. First account of a nesting population of Monk parakeets (Myiopsitta monachus) with nodule-shaped bill lesions in Katehaki, Athens, Greece. Bird Pop. 12:1-6.

Khan, H. A., M. Javed, A. Tahir, and M. Kanwal. 2013. Limiting the ring-necked parakeet (Psittacula krameri) damage on guava (Psidium guajava) and mango (Mangifera indica) with an ultrasonic sound player in a farmland in Faisalabad, Pakistan. Afr. J. Agric. Res. 8:6608-6614.

Klug, P. E., W. P. Bukoski, A. B. Shiels, B. M. Kluever, and S. R. Siers. 2019. Rose-ringed parakeets. Wildlife Damage Management Technical Series. USDA, APHIS, WS National Wildlife Research Center. Fort Collins, Colorado. 16 pp. https://www.aphis. usda.gov/wildlife_damage/reports/Wildlife \%20Damage\%20Management\%20Technical\%20Series/Rose\%20Ringed\%20Parakeet_WDM\%20Technical\%20Series.pdf

Komar, N., S. Langevin, S. Hinten, N. Nemeth, E. Edwards, D. Hettler, B. Davis, R. Bowen, and M. Bunning. 2003. Experimental infection of North American birds with the New York 1999 strain of west Nile virus. Emerg. Infect. Dis. 9:311-322.

Koopman, M. E., and W. C. Pitt. 2007. Crop diversification leads to diverse bird problems in Hawaiian agriculture. HumanWild. Conflicts 1:235-243.

Lamba, B. S. 1966. Nidification of some common Indian birds: 10. The rose-ringed 
parakeet, Psittacula krameri scopoli. Proc. Zool. Soc. Calcutta 19:77-85.

Lambert, M. S., G. Massei, J. Bell, C. Haigh, and D. P. Cowan. 2009. Reproductive success of rose-ringed parakeets Psittacula krameri in a captive UK population. Pest Manag. Sci. 65: 1215-1218.

Lambert, M. S., G. Massei, C. A. Yoder, and D. P. Cowan. 2010. An evaluation of Diazacon as a potential contraceptive in non-native rose-ringed parakeets. J. Wild. Manag. 74: 573-581.

Leven, M. R., and R. T. Corlett. 2004. Invasive birds in Hong Kong, China. Ornithol. Sci. 3:43-55.

Lever, C. 1987. Naturalised birds of the world. Longman Publishing, Harlow, U.K.

Linz, G. M. 2013. Blackbird population management to protect sunflower: A history. Proc. Wild. Damage Manag. Conf. 15:42-53.

Lockwood, J. L. 1999. Using taxonomy to predict success among introduced avifauna: relative importance of transport and establishment. Conserv. Biol. 13:560-567.

Lockwood, J. L., M. F. Hoopes, and M. P. Marchetti. 2007. Invasion ecology. Blackwell Publishing, Malden.

Lohr, C. A. 2012. Human dimensions of introduced terrestrial vertebrates in the Hawaiian Islands. Ph.D. diss., University of Hawai'i at Mānoa, Honolulu.

Mack, A. L., and D. D. Wright. 2005. The frugivore community and the fruiting plant flora in a New Guinea rainforest: identifying keystone frugivores. Pages 184-203 in J.L. Dew, and J.P. Boubli, eds. Tropical fruits and frugivores: The search for strong interactors. Springer, The Netherlands.

Mase, M., T. Imada, Y. Sanada, M. Etoh, N. Sanada, K. Tsukamoto, Y. Kawaoka, and S. Yamaguchi. 2001. Imported parakeets harbor H9N2 influenza A viruses that are genetically closely related to those transmitted to humans in Hong Kong. J. Virol. 75:3490-3494.

Matsunaga, S., and T. Fujii. 2018. Dietary preference of invasive rose-ringed parakeet Psittacula krameri manillensis around the Tokyo area. FBN 5:13-16.
Medeiros, A. C., L. L. Loope, P. Conant, and S. McElvaney. 1997. Status, ecology, and management of the invasive plant, Miconia calvescens DC (Melastomataceae) in the Hawaiian Islands. Bishop Museum Occasional Papers 48:23-36.

Menchetti, M., and E. Mori. 2014. Worldwide impact of alien parrots (Aves Psittaciformes) on native biodiversity and environment: a review. Ethol. Ecol. Evol. 26:172-194.

Menchetti, M., R. Scalera, and E. Mori. 2014. First record of a possibly overlooked impact by alien parrots on a bat (Nyctalus leisleri). Hystrix, Ital. J. Mammal. 25:61-62.

Menchetti, M., E. Mori, and F. M. Angelici. 2016. Chapter 12: Effects of the recent world invasion by ring-necked parakeets Psittacula krameri. Pages 253-266 in F. M. Angelici, ed. Problematic wildlife. Springer International Publishing, Switzerland.

Mentil, L., C. Battisti, and G. M. Carpaneto. 2018. The impact of Psittacula krameri (Scopoli, 1769) on orchards: first quantitative evidence for Southern Europe. Belg. J. Zool. 148:129-134.

Miskelly, C. M. 2015 [updated 2018]. Roseringed parakeet. In C. M. Miskelly, ed. New Zealand Birds Online. www.nzbird sonline.org.nz

Mori, E., L. Ancillotto, M. Menchetti, C. Romeo, and N. Ferrari. 2013. Italian red squirrels and introduced parakeets: victims or perpetrators? Hystrix, Ital. J. Mammal. 24:195-196.

Mukherjee, A., C. K. Borad, and B. M. Parasharya. 2000. Damage of rose-ringed parakeet, Psittacula krameri Bordeat, to safflower, Carthamus tinctorius L. Pavo 38:15-18.

Novak, S. 2018. Invasive parakeets are threatening every crop on the Hawaiian Island of Kauai-and multiplying fast. Modern Farmer, January 22, 2018. https://modernfarmer.com/2018/01/inva sive-rose-ringed-parakeets-threateningevery-crop-on-hawaiian-island-kauai/

Paton, P. W. C., C. R. Griffin, and L. H. MacIvor. 1982. Rose-ringed parakeet 
nesting in Hawai' $i$ : a potential agricultural threat. 'Elepaio 43:37-39.

Pennybacker, M. 2016. The rising parakeet population imperils farms and native plants, officials say. Star Advertiser, January 10, 2016. http://www.staradvertiser.com/ features/the-rising-parakeet-populationimperils-farms-and-native-plants-officialssay/ (Accessed May 1, 2016).

Pithon, J. A. 1998. The status and ecology of the ring-necked parakeet Psittacula krameri in Great Britain. Ph.D. diss., University of York, York.

Pithon, J. A., and C. Dytham. 1999. Breeding performance of ring-necked parakeets Psittacula krameri in small introduced populations in southeast England. Bird Study 46:342-347.

-2001. Determination of the origin of British feral rose-ringed parakeets. British Birds 94:74-79.

Pyle, R. L., and P. Pyle. 2009. The birds of the Hawaiian Islands: occurrence, history, distribution, and status. B.P. Bishop Museum, Honolulu, HI, U.S.A. Version 1 (31 December 2009). http://hbs.bishopmu seum.org/birds/rlp-monograph/

- 2017. The birds of the Hawaiian Islands: occurrence, history, distribution, and status. B.P. Bishop Museum, Honolulu, HI, U.S.A. Version 2 (1 January 2017). http://hbs.bishopmuseum.org/ birds/rlp-monograph/

Radford, A., and T. Penniman. 2014. Mitred conure control on Maui. Pages 61-66 in R. M. Timm and J. M. O'Brien, eds. Proc. Vert. Pest Conf. Univ. Calif. Press, Davis, CA.

Rao, G. S., and N. Shivanarayan. 1981. Note on the food of nestlings of rose-ringed parakeets in Hyderabad. Pavo 19:97-99.

Reddy, V. R. 1998a. Bird damage to maize crop on the student's research farm at Rajendranagar, Hyderabad, Andhra Pradesh. Pavo 36:77-78.

-1998b. Studies on damage to sorghum by the rose-ringed parakeet, Psittacula krameri, at Rajendranagar, Hyderabad, Andhra Pradesh. Pavo 36:79-80.

. 1999. Intensive damage to maize crop by rose-ringed parakeet at a student's farm in a maize cultivated crop in Rajendernager, Hyderabad, Andhrapradesh. Indian J. Forestry 3:16-18.

Reino, L., R. Figueira, P. Beja, M. B. Araújo, C. Capinha, and D. Strubbe. 2017. Network of global bird invasion altered by regional trade ban. Sci. Adv. 3:e1700783.

Roscoe, D. E., W. B. Stone, L. Petrie, and J. L. Renkavinsky. 1976. Exotic Psittacines in New York State. N.Y. Fish Game J. 23:99-100.

Runde, D. E., W. C. Pitt, and J. T. Foster. 2007. Population ecology and potential impacts of emerging populations of exotic parrots. Pages 338-360 in G. W. Witmer, W. C. Pitt, K. A. Fagerstone, eds. Managing vertebrate invasive species: Proceedings of an international symposium. USDA National Wildlife Research Center, Fort Collins, CO.

Sa, R. C., A. A. Cunningham, M. P. Dagleish, N. Wheelhouse, A. Pocknell, N. Borel, H. L. Peck, and B. Lawson. 2014. Psittacine beak and feather disease in a free-living ring-necked parakeet (Psittacula krameri) in Great Britain. Eur. J. Wildl. Res. 60:395-398 .

Saini, H. K., M. S. Dhindsa, and H. S. Toor. 1994. Food of the rose-ringed parakeet Psittacula krameri: a quantitative study. J. Bombay Nat. Hist. Soc. 91:96-103.

Scalera, R. 2001. Il parrocchetto dal collare Psittacula krameri. Pages 195-199 in R. Scalera, ed. Invasioni biologiche. Le introduzioni di vertebrati in Italia: un problema tra conservazione e globalizzazione. Corpo Forestale dello Stato e Ministero delle Politiche Agricole e Forestali, Rome.

Senar, J. C., L. Arroyo, A. Ortega-Segalerva, J. G. Carrillo, X. Tomás, T. Montalvo, and A. Sanz-Aguillar. 2019. Estimating agedependent survival when juveniles resemble females: invasive ring-necked parakeets as an example. Ecol. Evol. 9:891-898.

Shiels, A. B. 2011. Frugivory by introduced black rats (Rattus rattus) promotes dispersal of invasive plant seeds. Biol. Invasions 13:781-792.

Shiels, A. B., W. P. Bukoski, and S. R. Siers. 2018. Diets of Kauai's invasive rose-ringed parakeet 
(Psittacula krameri): evidence of seed predation and dispersal in a human-altered landscape. Biol. Invasions 20:1449-1457.

Shivanarayan, N. 1981. Note on the food of rose-ringed parakeet in Hyderabad. Pavo 19:97-99.

Shivanarayan, N., K. S. Babu, and M. H. Ali. 1981. Breeding biology of rose ringed parakeet Psittacula krameri at Maruteru. Pavo 19:92-96.

Skutch, A. F. 1983. Birds of tropical America. University of Texas Press, Austin.

Stone, E. G., G. Montiel-Parra, and T. M. Pérez. 2005. A survey of selected parasitic and viral pathogens in four species of Mexican parrots, Amazona autumnalis, Amazona oratrix, Amazona viridigenalis, and Rbynchopsitta pachyrhyncha. J. Zoo Wild. Med. 36:245-249.

Strubbe, D., and E. Matthysen. 2007. Invasive ring-necked parakeets Psittacula krameri in Belgium: habitat selection and impact on native birds. Ecography 30:578-588.

2009a. Predicting the potential distribution of invasive ring-necked parakeets Psittacula krameri in northern Belgium using an ecological niche modeling approach. Biol. Invasions 11:497-513.

2009b. Experimental evidence for nest-site competition between invasive ring-necked parakeets (Psittacula krameri) and native nuthatches (Sitta europaea). Biol. Conserv. 142:1588-1594.

- 2009c. Establishment success of invasive ring-necked and monk parakeets in Europe. J. Biogeography 36:2264-2278.

- 2011. A radiotelemetry study of habitat use by the exotic ringed-necked parakeet Psittacula krameri in Belgium. Ibis 153:180-184.

Strubbe, D., H. Jackson, J. Groombridge, and E. Matthysen. 2015. Invasion success of a global avian invader is explained by within-taxon niche structure and association with humans in the native range. Diversity Distrib. 21:675-685.

Tayleur, J. R. 2010. A comparison of the establishment, expansion and potential impacts of two introduced parakeets in the United Kingdom. Proceedings of the Conference: The Impacts of Non-Native species. British Ornithologists' Union, Peterborough, UK. https://www.bou.org.uk/bouproc net/impacts-of-non-native-species/.

Temara, K., and R. Arnhem. 1996. Perruches a collier (Psittacula krameri) victimes des conditions climatiques en region Bruxelloise. Aves 33:128-129.

Thabethe, V., A.-L. Wilson, L. A. Hart, and C. T. Downs. 2015. Ingestion by an invasive parakeet reduces germination success of invasive alien plants relative to ingestion by indigenous turaco species in South Africa. Biol. Invasions 17:3029-3039.

Tozer, R. B. 1974. Feral parakeets and control of introductions. British Birds 67:484-485.

Traffic U.S.A. 1987. U.S. imports of parrots from Latin America. Traffic Bull. 7:5-8.

VanderWerf, E. A., and N. P. Kalodimos. In review. Status of naturalized parrot populations in the Hawaiian Islands. Pages $\mathrm{xx}-\mathrm{xx}$ in S. Pruett-Jones, ed. Naturalized parrots of the world.

Van Kleunen, A., L. Van den Bremer, R. Lensink, and P. Wiersma. 2010. De Halsbandparkiet, Monniksparkiet en Grote Alexanderparkiet in Nederland: risicoanalyse en beheer. SOVON- onderzoeksrapport 2010/10 Dit rapport is samengesteld in opdracht van Team Invasieve Exoten van het Ministerie van Landbouw, Natuur en Voedselkwaliteit.

Vicentini, A., and E. A. Fischer. 1999. Pollination of Moronobea coccinea (Clusiaceae) by the golden-winged parakeet in the central Amazon. Biotropica 31:692-696. 